\title{
Morphology, molecular phylogeny and okadaic acid production of epibenthic Prorocentrum (Dinophyceae) species from the northern South China Sea
}

\author{
Zhaohe Luo $^{\mathrm{a}, \mathrm{b}, 1}$, Hua Zhang ${ }^{\mathrm{a}, 1}$, Bernd Krock $^{\mathrm{c}}$, Songhui Lu ${ }^{\mathrm{a}, *}$, Weidong Yang ${ }^{\mathrm{a}}$, Haifeng Gu ${ }^{\mathrm{b}, *}$ \\ a College of Life Science and Technology, Jinan University, Guangzhou 510632, China \\ ${ }^{\mathrm{b}}$ Third Institute of Oceanography, SOA, Xiamen 361005, China \\ ${ }^{\text {c }}$ Alfred Wegener Institute for Polar and Marine Research, Am Handelshafen 12, D-27570 Bremerhaven, Germany
}

\section{A R T I C L E I N F O}

\section{Article history:}

Received 21 June 2016

Received in revised form 26 October 2016

Accepted 27 November 2016

Available online $\mathrm{xxxx}$

\section{Keywords:}

Diarrheic shellfish poisoning

Okadaic acid

Prorocentrum emarginatum

Prorocentrum hoffmannianum

Prorocentrum maculosum

Prorocentrum panamense

\begin{abstract}
A B S T R A C T
Around 30 epibenthic Prorocentrum species have been described, but information about their biogeography is limited. Some species are able to produce okadaic acid (OA) and its derivatives, which are responsible for diarrheic shellfish poisoning (DSP). In the present study, we examined the diversity of epibenthic Prorocentrum in the northern South China Sea by isolating single cells from sand, coral, and macroalgal samples collected from 2012 to 2015. Their morphology was examined using light microscopy and scanning electron microscopy. Among 47 Prorocentrum strains, seven morphospecies were identified as $P$. lima, P. rhathymum, P. concavum, $P$. cf. emarginatum, $P$. fukuyoi, $P$. cf. maculosum and $P$. panamense. The latter five species have not been previously reported in Chinese waters, and this is the first record of $P$. panamense outside its type locality. Partial large subunit (LSU) ribosomal DNA and internal transcribed spacer region sequences were obtained and molecular phylogenetic analysis was carried out using maximum likelihood and Bayesian inference. Chinese P. cf. maculosum strains share 99.5\% similarity of LSU sequences with the strain from Cuba (close to the type locality), but Chinese $P$. lima strains share only $96.7 \%$ similarity of LSU sequences with the strain from the type locality. $P$. cf. emarginatum differs from $P$. fukuyoi mainly in the presence/absence of marginal pores and they form a wellresolved clade together with $P$. sculptile. OA was detected in all Chinese strains of $P$. lima and $P$. cf. maculosum based on liquid chromatography-mass spectrometry analysis, but dinophysistoxin was produced only by two $P$. lima strains. Chinese strains of $P$. concavum, P. rhathymum, and P. panamense do not produce detectable level of OA. Our results support the wide distribution of epibenthic Prorocentrum species and highlight the potential risk of DSP in the northern South China Sea.
\end{abstract}

(c) 2016 Published by Elsevier B.V.

\section{Introduction}

Among dinoflagellates, the prorocentroid tabulation is characterized by the lack of a girdle and sulcus and by the presence of an apical periflagellar area where two flagella emerge. The order Prorocentrales was established to incorporate prorocentroid species, and it contains a single family (Prorocentraceae) and three genera (Prorocentrum Ehrenberg, Haplodinium Kleb, and Mesoporus Lillick) [23]. Haplodinium might be a junior synonym of Prorocentrum [46], and the phylogenetic position of Mesoporus remains to be determined.

The genus Prorocentrum was erected with P. micans Ehrenberg as the type species [17]. Later, Exuviaella Cienkowski was established to include E. marina Cienkowski (= P. lima (Ehrenberg) F. Stein) [10]. These two genera differ only in the presence or absence of an apical

\footnotetext{
* Corresponding authors.

E-mail addresses: lusonghui1963@163.com (S. Lu), guhaifeng@tio.org.cn (H. Gu).

1 These authors contribute equally.
}

spine, and Abe [1] proposed that they be merged. [16] formally made Exuviaella a junior synonym of Prorocentrum and reduced the number of Prorocentrum species from 64 to 21 (most of them are planktonic), as great infraspecific variations were observed.

The genus Prorocentrum currently contains approximately 80 species divided nearly equally among planktonic and epibenthic lifestyles. Epibenthic Prorocentrum species inhabit intertidal marine sediments, macroalgal surfaces, floating detritus and corals [21]. The presumable epibenthic species (e.g., P. arabianum Morton \& Faust ( = P. concavum Fukuyo) and P. rhathymum A. R. Loeblich III, Sherley \& Schmidt) can also be recovered from the plankton [12,50].

The morphology of Prorocentrum is rather simple, consisting of two large plates (valves) and a periflagellar area with several platelets. The useful characters for differentiation at the species level include cell shape and size, thecal plate surface (ornamentation and pore patterns), intercalary band morphology, and the number and shape of platelets and relevant structure (e.g., spines, collars, and protrusions in the periflagellar area). Among these traits, the periflagellar structure is 
regarded as being conservative and significant for differentiating species [33]. Other features such as cell shape and the number and shape of thecal pores have been reported to be variable $[19,57,74]$. The details of the periflagellar area in some species (e.g., P. fukuyoi S. Murray \& Y. Nagahama) are still not clear [33]. Despite their morphological synapomorphies, Prorocentrum appeared to be polyphyletic or palyphyletic based on either small subunit (SSU) or large subunit ribosomal DNA (LSU rDNA) sequences [25,53]. However, they appeared to be monophyletic once concatenated data, especially from mitochondrial sequences, were used $[59,73]$.

In view of the high morphological similarity among Prorocentrum species, it is not surprising that some species have been described repeatedly. For instance, $P$. arabianum, $P$. arenarium Faust and $P$. minimum (Pavillard) Schiller are now considered to be synonyms of $P$. concavum, $P$. lima, and $P$. cordatum (Ostenfeld) Dodge, respectively $[48,57,70]$. P. mexicanum Osorio-Tafall and $P$. rhathymum, as well as P. hoffmannianum Faust and P. belizeanum Faust might be conspecific as well $[12,30]$. P. maculosum Faust was described from Twin Cays, Belize and differs from P. lima only in the shape of valve pores and the relative size of flagella and accessory pores [20]. $P$. emarginatum Fukuyo was described from Okinawa, Japan using light microscopy [24]. To date, detailed morphology and molecular sequence data for $P$. emarginatum from the type locality are not available. P. fukuyoi differs from $P$. emarginatum mainly in cell shape, but $P$. fukuyoi is genetically very close to $P$. emarginatum from Fiji [54]. Thus, detailed information about $P$. maculosum and $P$. emarginatum is needed to understand the species boundaries.

Most epibenthic Prorocentrum species have been described from tropical or subtropical areas, but some can inhabit temperate areas. P. lima is considered to be a cosmopolitan species [57], and some species, including $P$. rhyathymum and $P$. concavum, are known to have a wide distribution $[3,4,24,43]$. In contrast, other species are rarely reported. For instance, P. panamense Grzebyk, Sako \& Berland and $P$. maculosum have been reported only from Central America $[20,25]$.

The most interesting feature of Prorocentrum is that some species are able to produce okadaic acid (OA) and its related derivatives (dinophysistoxins, DTXs), which are responsible for diarrheic shellfish poisoning (DSP). Some Prorocentrum species can produce other toxins as well, such as prorocentin [45] and formosalides [44]. OA is a polyether derivative of 38-carbon fatty acid and was first isolated from two marine sponges [65]. It is a potent tumor promoter that is a powerful inhibitor of protein phosphatases- 1 and $-2 A[31,66]$. Human diarrheic poisonings have occurred due to consumption of clams and crabs contaminated with OA esters [68]. OA production has been reported in epibenthic $P$. lima, P. rhathymum, P. hoffmannianum, P. maculosum, $P$. levis M.A. Faust, Kibler, Vandersea, P.A. Tester \& Litaker, and $P$. belizeanum and in one planktonic species $P$. texanum Henrichs, Steidinger, Scott \& Campbell $[5,22,29,49,51,52,76]$. P. lima strains are always toxic, producing $\mathrm{OA}$ and its analogues in varying quantities $[7,32$, $67,72]$. P. rhathymum from Florida, USA and Malaysia can produce OA [5, 8], but those from Okinawa, Japan [72] and Greece [3] do not produce detectable toxin based on bioassay and protein phosphatase $2 \mathrm{~A}$ inhibition assay. To date, OA production by $P$. maculosum has been reported qualitatively only [76]. Thus, OA production in more epibenthic Prorocentrum strains needs to be examined to better understand its prevalence.

Ten epibenthic Prorocentrum species have been reported from East Malaysia [47], and four have been reported in Vietnam waters [39]. So far, only P. lima and P. rhathymum have been reported in Chinese waters $[42,74]$, but a richer diversity of epibenthic Prorocentrum can be expected. OA was detected in shellfish harvested from the South China Sea [71], but OA production was confirmed in only one strain of P. lima from Hainan [41]. The goal of the present study was to fully understand the diversity and OA production of epibenthic Prorocentrum species in the northern South China Sea.

\section{Materials and methods}

\subsection{Sample collection and treatment}

Samples were collected from ten stations in the northern South China Sea from 2012 to 2015 (Fig. 1, for geographical coordinates see Table 1). The macroalgal, seagrass, dead coral reef and upper centimeter of sandy sediments were collected from the seabed by scuba divers, and deposited into bottles containing seawater collected at the same location. The samples were stirred vigorously to detach the epibenthic cells and the suspension settled in a composite settling chamber. The settled materials were subsequently sieved through $120 \mu \mathrm{m}$ and $20 \mu \mathrm{m}$ filters. The $20-120 \mu \mathrm{m}$ fractions were rinsed with filtered seawater and transferred into a polycarbonate bottle. In the laboratory, single live cells were isolated from this material with a micropipette under an inverted microscope Eclipse TS100 (Nikon, Tokyo, Japan) into a 96-well culture plate containing $330 \mu \mathrm{L} \mathrm{f/2-Si} \mathrm{medium} \mathrm{[27]} \mathrm{or} \mathrm{L1} \mathrm{medium} \mathrm{[26].}$ The culture plate was incubated at $25^{\circ} \mathrm{C}, 90 \mu \mathrm{mol}$ photons $\mathrm{m}^{-2} \mathrm{~s}^{-1}$, and a light:dark cycle of $12 \mathrm{~h}: 12 \mathrm{~h}$ (hereafter, called "standard culture conditions"). The cultures were transferred to a 6 -well culture plate later under the standard culture conditions.

\subsection{Light microscopy (LM)}

Live cells were examined and photographed using a Zeiss Axio Imager microscope (Carl Zeiss, Göttingen, Germany) equipped with a Zeiss Axiocam HRc digital camera, or an Olympus BX 61 (Olympus, Tokyo, Japan) equipped with a QImaging Retiga 4000R digital camera (QImaging, Surrey, British Columbia, Canada). More than thirty cells were measured using Axiovision (4.8.2 version) or IMG Pro plus (6.0 version) software at $\times 400$ magnification. To observe the shape and location of the nucleus, cells were stained with 1:100,000 Sybr Green (Sigma Aldrich, St. Louis, USA) for $1 \mathrm{~min}$, and photographed under the Zeiss fluorescence microscope with a Zeiss-38 filter set (excitation BP 470/40, beam splitter FT 495, emission BP 525/50). Chloroplast autofluorescence microscopy was carried out on live cells using a Leica DM6000B fluorescence microscope (Leica Microsystems, Wetzlar, Germany) equipped with a B/G/R filter cube (blue: emission filter BP420/ 30 , dichromatic mirror 415 , suppression filter BP465/20; green: BP495/15, 510, BP530/30; red: BP570/20, 590, BP640/40), and digitally photographed using a Leica DFC300 FX digital camera.

\subsection{Scanning electron microscopy (SEM)}

Mid-exponential batch cultures were concentrated by a Sorvall Biofuge Primo R (Thermo Scientific, Massachusetts, USA) at $1250 \mathrm{~g}$ for $10 \mathrm{~min}$ at room temperature. The cell pellet was re-suspended in 60\% ethanol for $1 \mathrm{~h}$ at $8{ }^{\circ} \mathrm{C}$ to strip off the mucilage. The cells were centrifuged again to remove the ethanol and the pellet was fixed at $8{ }^{\circ} \mathrm{C}$ for $3 \mathrm{~h}$ with $5 \%$ glutaraldehyde prepared with filtered seawater. Cell pellets were washed twice with filtered seawater and fixed overnight at $8{ }^{\circ} \mathrm{C}$ with $2 \% \mathrm{OsO}_{4}$ made up with filtered seawater. The supernatant was removed and the cell pellet was allowed to adhere to a coverslip coated with poly-L-lysine (molecular weight 70,000-150,000). Subsequently, cells were washed in Milli-Q water for $10 \mathrm{~min}$ and dehydrated through a graded ethanol series $(10,30,50,70,90$ and $3 \times$ in $100 \%)$ for 10 min at each step. The samples were then critical point dried in a K850 Critical Point Dryer (Quorum/Emitech, West Sussex, UK), sputter-coated with gold, and examined with a Zeiss Sigma FE (Carl Zeiss Inc., Oberkochen, Germany) or a Zeiss Ultra 55 FE (Zeiss, Jena, Germany) scanning electron microscope. Images were presented on a black background using Adobe Photoshop CC2014. The standard terminology proposed by Hoppenrath et al. [33] was applied for the description of morphological features, cell orientation and number of platelets. 


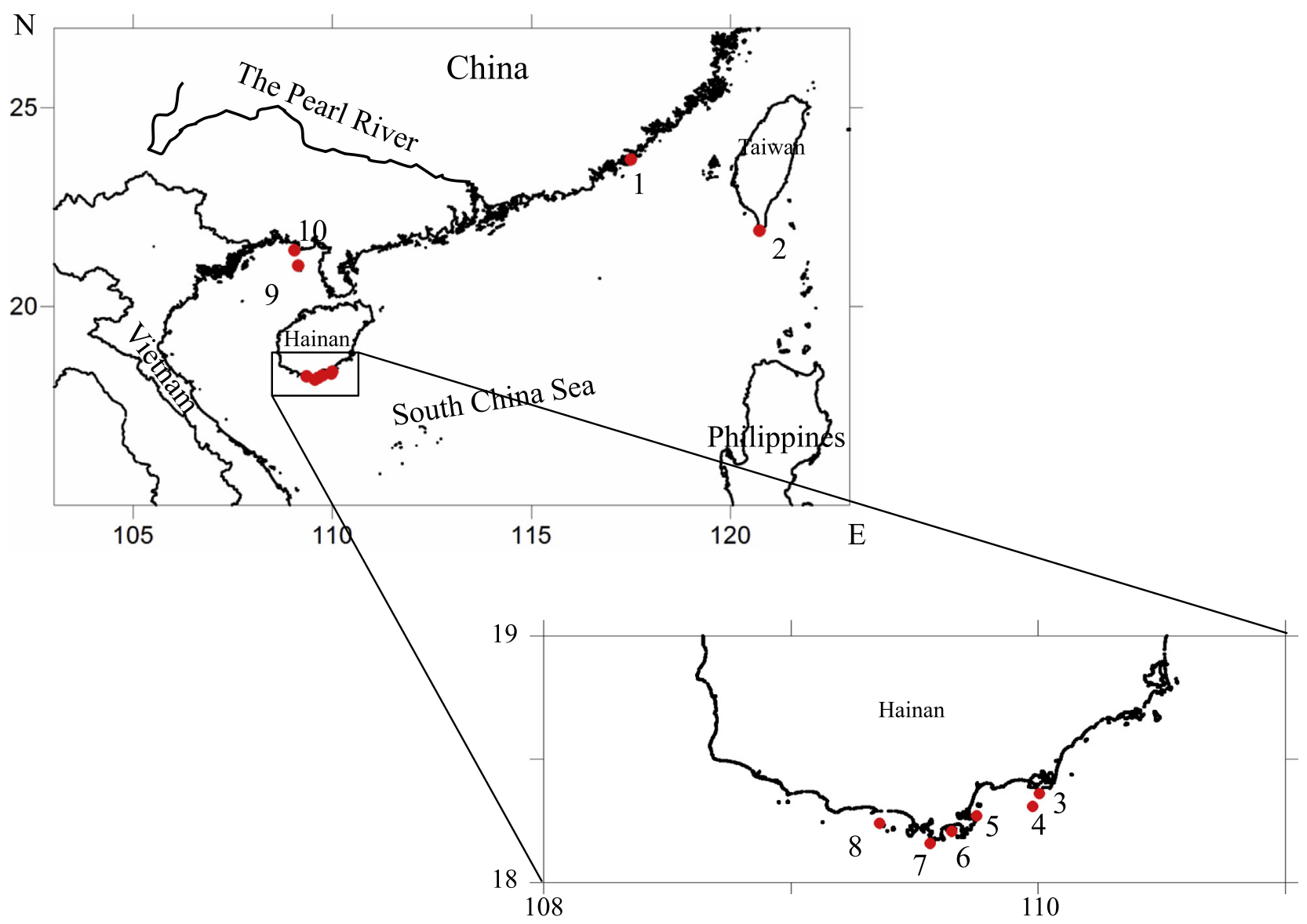

Fig. 1. Map of sampling locations in the northern South China Sea.

\subsection{PCR amplifications and sequencing}

Total genomic DNA was extracted from $50 \mathrm{~mL}$ of exponentially growing cultures using a MiniBEST Universal DNA Extraction Kit (Takara, Tokyo, Japan) according to the manufacturer's protocol. PCR amplifications were carried out using $1 \times$ PCR buffer, $50 \mu \mathrm{M}$ dNTP mixture, $0.2 \mu \mathrm{M}$ of each primer, $10 \mathrm{ng}$ of template genomic DNA, and $1 \mathrm{U}$ of ExTaq DNA Polymerase (Takara, Tokyo, Japan) in $50 \mu \mathrm{L}$ reactions. The total ITS1-5.8S-ITS2 was amplified using ITSA/ITSB [2] or ITSF/ITSR [40] primers. The LSU rDNA was amplified using the primers of D1R/ 28-1483R [13,63] (see Table 2). The thermal cycle procedure was $4 \mathrm{~min}$ at $94^{\circ} \mathrm{C}$, followed by 30 cycles of $1 \mathrm{~min}$ at $94^{\circ} \mathrm{C}, 1 \mathrm{~min}$ at $45^{\circ} \mathrm{C}$, $1 \mathrm{~min}$ at $72^{\circ} \mathrm{C}$, and final extension of $7 \mathrm{~min}$ at $72^{\circ} \mathrm{C}$ with a Mastercycler (Eppendorf, Hamburg, Germany). The PCR product was purified using a DNA purification kit (Shangong, Shanghai, China) and sequenced directly in both directions on an ABI PRISM 3730XL (Applied Biosystems, Foster City, CA, USA) following the manufacturer's instructions. Sequences were deposited in the GenBank with accession numbers KY010226 to KY010266.

\subsection{Sequence alignment and phylogenetic analyses}

Newly obtained LSU rDNA (D1-D6) and ITS region sequences were aligned with related sequences downloaded from the GenBank using MAFFT v7.110 [36] online program (http://mafft.cbrc.jp/alignment/ server/) [9]. Aligned sequences were manually checked with BioEdit v. 7.2 .5 [28]. Adenoides eludens and Pseudadenoides kofoidii were used for the outgroup of LSU and ITS based phylogeny, respectively. For Bayesian inference (BI), the program jModelTest [15] was used to select the most appropriate model of molecular evolution with Akaike Information
Criterion (AIC). Bayesian reconstruction of the data matrix was performed using MrBayes 3.2 [61] with the best-fitting substitution model (TIM1 + G). Four Markov chain Monte Carlo (MCMC) chains ran for 2,000,000 generations, sampling every 100 generations. Convergence diagnostics were graphically estimated using AWTY (http://ceb. scs.fsu.edu/awty) [58] and the first $10 \%$ of burn-in trees were discarded. A majority rule consensus tree was created in order to examine the posterior probabilities of each clade. Maximum likelihood (ML) analyses were conducted with RaxML v7.2.6 [64] on the T-REX web server [6] using the model GTR + G. Node support was assessed with 1000 bootstrap replicates.

\subsection{Determination of okadaic acid (OA) and dinophysistoxins (DTXs)}

Mid-exponential batch cultures were harvested by a Sorvall Biofuge Primo R (Thermo Scientific, Massachusetts, USA) at $1250 \mathrm{~g}$ for $10 \mathrm{~min}$. Cell pellets were suspended in $500 \mu \mathrm{L}$ methanol, and homogenized with $0.9 \mathrm{~g}$ of lysing matrix D by reciprocal shaking at maximum speed $\left(6.5 \mathrm{~m} \mathrm{~s}^{-1}\right)$ for $45 \mathrm{~s}$ in a Bio101 FastPrep instrument (Thermo Savant, Illkirch, France). After homogenization, each sample was centrifuged at $16,100 \mathrm{~g}$ at $4{ }^{\circ} \mathrm{C}$ for $15 \mathrm{~min}$. The supernatant was transferred to a spin-filter ( $0.45 \mu \mathrm{m}$ pore-size, Millipore Ultrafree, Eschborn, Germany) and centrifuged for $30 \mathrm{~s}$ at $800 \mathrm{~g}$, followed by transfer to autosampler vials. Analysis of multiple lipophilic toxins was performed by liquid chromatography coupled to tandem mass spectrometry (LC-MS/MS), as described in Krock et al. [38] with minor modifications including an extended list of screened phycotoxins (Table S1).

Okadaic acid was quantified by external calibration using a standard solution obtained from the Certified Reference Material programme of the Institute of Marine Biology (IMB) of the National Research Council 
Table 1

Chinese strains of Prorocentrum examined in the present study, including okadaic acid concentrations, collection data and locations.

\begin{tabular}{|c|c|c|c|c|c|c|c|c|}
\hline Species & Strains & Okadaic acid (fg cell ${ }^{-1}$ ) & DTX-1 (fg cell $\left.{ }^{-1}\right)$ & Collection date & Latitude (N) & Longitude (E) & Stations & Location \\
\hline P. concavum & AS4F7 & - & - & 2013.06.08 & $18^{\circ} 18.63^{\prime}$ & $109^{\circ} 58.62^{\prime}$ & 4 & Lingshui, Hainan \\
\hline P. concavum & DS4C10 & $<0.031$ & None & 2013.06.08 & $18^{\circ} 18.63^{\prime}$ & $109^{\circ} 58.62^{\prime}$ & 4 & Lingshui, Hainan \\
\hline P. concavum & DS4E11 & $<0.015$ & None & 2013.06.08 & $18^{\circ} 18.63^{\prime}$ & $109^{\circ} 58.62^{\prime}$ & 4 & Lingshui, Hainan \\
\hline P. concavum & DS4F8 & - & - & 2013.06.08 & $18^{\circ} 18.63^{\prime}$ & $109^{\circ} 58.62^{\prime}$ & 4 & Lingshui, Hainan \\
\hline P. cf. emarginatum & $\mathrm{X} 2 \mathrm{P} 3$ & - & - & 2014.08 .19 & $18^{\circ} 14.47^{\prime}$ & $109^{\circ} 21.50^{\prime}$ & 8 & Sanya, Hainan \\
\hline P. fukuyoi & NG2 & - & - & 2012.11 .23 & $18^{\circ} 18.63^{\prime}$ & $109^{\circ} 58.62^{\prime}$ & 4 & Lingshui, Hainan \\
\hline P. fukuyoi & TI0309 & - & - & 2015.12 .03 & $21^{\circ} 25.24^{\prime}$ & $109^{\circ} 02.69^{\prime}$ & 10 & Beihai, Guangxi \\
\hline P. fukuyoi & TIO310 & - & - & 2015.12 .03 & $21^{\circ} 25.24^{\prime}$ & $109^{\circ} 02.69^{\prime}$ & 10 & Beihai, Guangxi \\
\hline P. fukuyoi & TIO312 & - & - & 2015.12 .03 & $21^{\circ} 25.24^{\prime}$ & $109^{\circ} 02.69^{\prime}$ & 10 & Beihai, Guangxi \\
\hline P. fukuyoi & TIO313 & - & - & 2015.12 .03 & $21^{\circ} 25.24^{\prime}$ & $109^{\circ} 02.69^{\prime}$ & 10 & Beihai, Guangxi \\
\hline P. fukuyoi & TIO314 & - & - & 2015.12 .03 & $21^{\circ} 25.24^{\prime}$ & $109^{\circ} 02.69^{\prime}$ & 10 & Beihai, Guangxi \\
\hline P. lima & TIO124 & 2834 & None & 2015.06.06 & $21^{\circ} 01.89^{\prime}$ & $109^{\circ} 08.48^{\prime}$ & 9 & Beihai, Guangxi \\
\hline P. lima & TI0177c & 2614 & None & 2015.06.06 & $21^{\circ} 01.89^{\prime}$ & $109^{\circ} 08.48^{\prime}$ & 9 & Beihai, Guangxi \\
\hline P. lima & TI0155a & 4213 & None & 2015.06.06 & $21^{\circ} 01.89^{\prime}$ & $109^{\circ} 08.48^{\prime}$ & 9 & Beihai, Guangxi \\
\hline P. lima & TIO155b & 2886 & None & 2015.06.06 & $21^{\circ} 01.89^{\prime}$ & $109^{\circ} 08.48^{\prime}$ & 9 & Beihai, Guangxi \\
\hline P. lima & TIO162 & 5110 & 910 & 2015.06 .06 & $21^{\circ} 01.89^{\prime}$ & $109^{\circ} 08.48^{\prime}$ & 9 & Beihai, Guangxi \\
\hline P. lima & TI0164 & 2601 & None & 2015.06.06 & $21^{\circ} 01.89^{\prime}$ & $109^{\circ} 08.48^{\prime}$ & 9 & Beihai, Guangxi \\
\hline P. lima & ТІ0302 & 10,260 & 1810 & 2015.08 .26 & $21^{\circ} 54.29^{\prime}$ & $120^{\circ} 43.55^{\prime}$ & 2 & Kending, Taiwan \\
\hline P. lima & TI0163 & 1275 & None & 2015.06 .06 & $21^{\circ} 01.89^{\prime}$ & $109^{\circ} 08.48^{\prime}$ & 9 & Beihai, Guangxi \\
\hline P. lima & TIO175c & 551 & None & 2015.06 .06 & $21^{\circ} 01.89^{\prime}$ & $109^{\circ} 08.48^{\prime}$ & 9 & Beihai, Guangxi \\
\hline P. cf. maculosum & TI011 & 5200 & None & 2014.11.16 & $18^{\circ} 09.61^{\prime}$ & $109^{\circ} 33.77^{\prime}$ & 7 & Sanya, Hainan \\
\hline P.cf. maculosum & TI0102 & 3317 & None & 2015.04 .16 & $18^{\circ} 12.48^{\prime}$ & $109^{\circ} 38.95^{\prime}$ & 6 & Sanya, Hainan \\
\hline P. cf. maculosum & TI0139 & 3002 & None & 2015.04 .16 & $18^{\circ} 16.26^{\prime}$ & $109^{\circ} 44.99^{\prime}$ & 5 & Sanya, Hainan \\
\hline P. cf. maculosum & TI0138 & 4269 & None & 2015.04 .16 & $18^{\circ} 16.26^{\prime}$ & $109^{\circ} 44.99^{\prime}$ & 5 & Sanya, Hainan \\
\hline P. cf. maculosum & TI0179 & 6879 & None & 2015.06.06 & $21^{\circ} 01.89^{\prime}$ & $109^{\circ} 08.48^{\prime}$ & 9 & Beihai, Guangxi \\
\hline P. cf. maculosum & TI0180 & 7610 & None & 2015.06.06 & $21^{\circ} 01.89^{\prime}$ & $109^{\circ} 08.48^{\prime}$ & 9 & Beihai, Guangxi \\
\hline P. panamense & TIO97 & $<0.341$ & None & 2015.04 .16 & $18^{\circ} 12.48^{\prime}$ & $109^{\circ} 38.95^{\prime}$ & 6 & Sanya, Hainan \\
\hline P. rhathymum & TIO29 & $<0.024$ & None & 2015.02 .05 & $18^{\circ} 16.26^{\prime}$ & $109^{\circ} 44.99^{\prime}$ & 5 & Sanya, Hainan \\
\hline P. rhathymum & TI0100 & $<0.015$ & None & 2015.04 .16 & $18^{\circ} 12.48^{\prime}$ & $109^{\circ} 38.95^{\prime}$ & 6 & Sanya, Hainan \\
\hline P. rhathymum & ТIO307 & - & - & 2015.10 .18 & $23^{\circ} 41.59^{\prime}$ & $117^{\circ} 29.67^{\prime}$ & 1 & Dongshan, Fujian \\
\hline P. rhathymum & TIO43 & - & - & 2015.02 .04 & $18^{\circ} 09.61^{\prime}$ & $109^{\circ} 33.77^{\prime}$ & 7 & Sanya, Hainan \\
\hline P. rhathymum & TIO52 & - & - & 2015.02 .04 & $18^{\circ} 09.61^{\prime}$ & $109^{\circ} 33.77^{\prime}$ & 7 & Sanya, Hainan \\
\hline P. rhathymum & TI055 & $<0.017$ & None & 2015.02 .04 & $18^{\circ} 09.61^{\prime}$ & $109^{\circ} 33.77^{\prime}$ & 7 & Sanya, Hainan \\
\hline P. rhathymum & TI071a & - & - & 2015.02 .04 & $18^{\circ} 09.61^{\prime}$ & $109^{\circ} 33.77^{\prime}$ & 7 & Sanya, Hainan \\
\hline P. rhathymum & TIO75 & - & - & 2015.02 .04 & $18^{\circ} 09.61^{\prime}$ & $109^{\circ} 33.77^{\prime}$ & 7 & Sanya, Hainan \\
\hline P. rhathymum & TIO80 & - & - & 2015.02 .04 & $18^{\circ} 09.61^{\prime}$ & $109^{\circ} 33.77^{\prime}$ & 7 & Sanya, Hainan \\
\hline P. rhathymum & TI082 & - & - & 2015.02 .04 & $18^{\circ} 09.61^{\prime}$ & $109^{\circ} 33.77^{\prime}$ & 7 & Sanya, Hainan \\
\hline P. rhathymum & TI0136 & - & - & 2015.04 .16 & $18^{\circ} 16.26^{\prime}$ & $109^{\circ} 44.99^{\prime}$ & 5 & Sanya, Hainan \\
\hline P. rhathymum & TI0146 & - & - & 2015.04 .16 & $18^{\circ} 16.26^{\prime}$ & $109^{\circ} 44.99^{\prime}$ & 5 & Sanya, Hainan \\
\hline P. rhathymum & TI0101 & $<0.014$ & None & 2015.04 .16 & $18^{\circ} 12.48^{\prime}$ & $109^{\circ} 38.95^{\prime}$ & 6 & Sanya, Hainan \\
\hline P. rhathymum & TI085 & $<0.014$ & None & 2015.04 .16 & $18^{\circ} 16.26^{\prime}$ & $109^{\circ} 44.99^{\prime}$ & 5 & Sanya, Hainan \\
\hline P. rhathymum & TIO84 & - & - & 2015.04 .16 & $18^{\circ} 16.26^{\prime}$ & $109^{\circ} 44.99^{\prime}$ & 5 & Sanya, Hainan \\
\hline P. rhathymum & TI093 & $<0.016$ & None & 2015.04 .17 & $18^{\circ} 21.63^{\prime}$ & $110^{\circ} 00.19^{\prime}$ & 3 & Sanya, Hainan \\
\hline P. rhathymum & TI0152 & - & - & 2015.04 .16 & $18^{\circ} 12.48^{\prime}$ & $109^{\circ} 38.95^{\prime}$ & 6 & Sanya, Hainan \\
\hline P. rhathymum & TI094 & - & - & 2015.04 .17 & $18^{\circ} 21.63^{\prime}$ & $110^{\circ} 00.19^{\prime}$ & 3 & Sanya, Hainan \\
\hline P. rhathymum & TI0109 & - & - & 2015.04 .17 & $18^{\circ} 21.63^{\prime}$ & $110^{\circ} 00.19^{\prime}$ & 3 & Sanya, Hainan \\
\hline P. rhathymum & TI0112 & - & - & 2015.04 .17 & $18^{\circ} 21.63^{\prime}$ & $110^{\circ} 00.19^{\prime}$ & 3 & Sanya, Hainan \\
\hline
\end{tabular}

(NRC), Halifax, NB, Canada. The detection limit was set as 24 pg per sample.

\section{Results}

Forty-seven strains of Prorocentrum were established from the northern South China Sea. Twenty strains were identified as $P$. rhathymum, 9 strains as $P$. lima, 6 strains as $P$. cf. maculosum, 6 strains as $P$. fukuyoi, 4 strains as $P$. concavum, 1 strain as $P$. cf. emarginatum

Table 2

Primers used to amplify ITS and partial LSU in dinoflagellate.

\begin{tabular}{lllll}
\hline Name & $\begin{array}{l}\text { Target } \\
\text { sequence }\end{array}$ & Direction & Sequence $\left(5^{\prime}-3^{\prime}\right)$ & References \\
\hline ITSA & ITS1-5.8S-ITS2 & Forward & CCTCGTAACAAGGHTCCGTAGGT & {$[2]$} \\
ITSB & ITS1-5.8S-ITS2 & Reverse & CAGATGCTTAARTCAGCRGG & {$[2]$} \\
ITSF & ITS1-5.8S-ITS2 & Forward & TCGTAACAAGGTTTCCGTAGGTG & {$[40]$} \\
ITSR & ITS1-5.8S-ITS2 & Reverse & ATATGCTTAAGTTCAGCGGG & {$[40]$} \\
D1R & LSU rDNA & Forward & ACCCGCTGAATTAAGCATA & {$[63]$} \\
28-1483R & LSU rDNA & Reverse & GCTACTACCACCAAGATCTGC & {$[13]$} \\
\hline
\end{tabular}

and 1 strain as $P$. panamense (Table 1 ). OA was detected in all P. lima and $P$. cf. maculosum strains.

\subsection{Morphology}

\subsubsection{Prorocentrum concavum Fukuyo (Fig. 2)}

Synonym: Prorocentrum arabianum Morton \& Faust

Cells of $P$. concavum were broad oval to ovoid, symmetric, and dorsoventrally flattened (Fig. 2A and B). They were 45.7-50.2 $\mu \mathrm{m}$ long (mean $47.9 \pm 1.0 \mu \mathrm{m}, n=62$ ) and 37.7-42.4 $\mu$ m wide (mean $39.6 \pm 1.2 \mu \mathrm{m}$, $n=62$ ), with the length/width ratio varying from 1.18 to 1.23 . There was a slightly elongated nucleus located in the posterior end of the cell (Fig. 2C). A presumable pyrenoid with a starch ring was situated in the cell center, with numerous chloroplasts radiating from the pyrenoid to the periphery (Fig. 2D). The thecal surface was full of round to oval depressions and ornamented with scattered pores $(0.13-0.27 \mu \mathrm{m}$ in diameter), which tended to be denser towards the margin (Fig. 2E$G$ ). Pores were absent in the central part of the cell and there were no marginal pores (Fig. 2E and F). The intercalary band had horizontal striations (Fig. 2G). The periflagellar area was wide V-shaped consisting of eight or nine platelets (1a, b, 2, 3, 4, 5, 6, 7, 8) (Fig. 2H and I). The flagella 

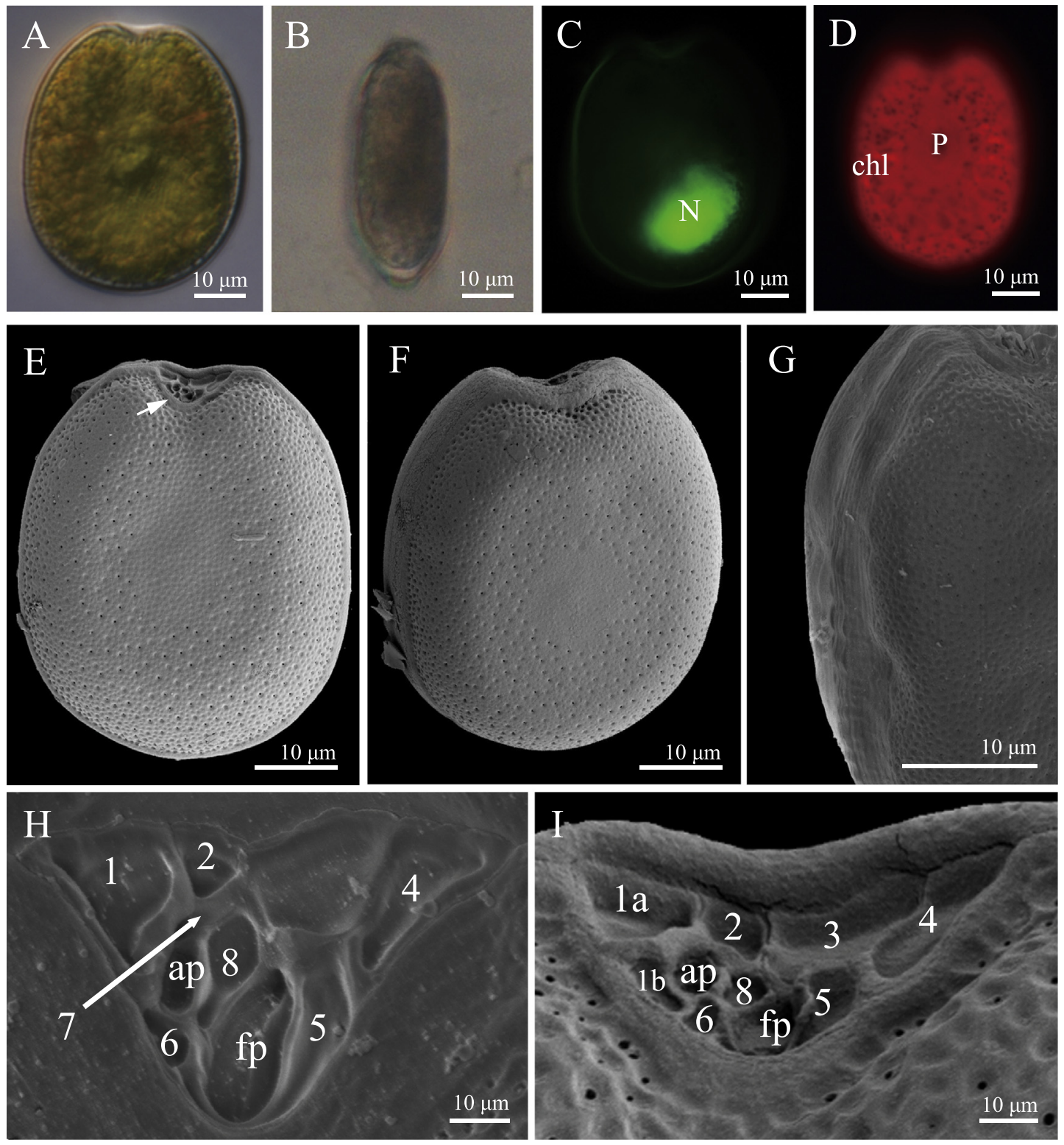

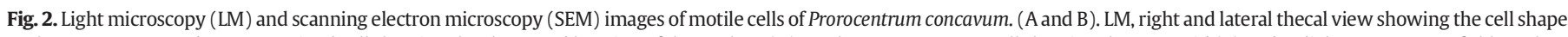

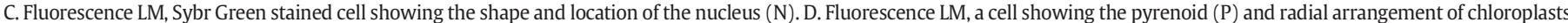

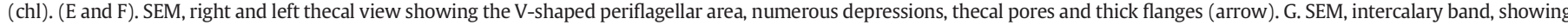

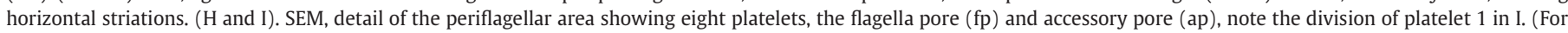
interpretation of the references to colour in this figure legend, the reader is referred to the web version of this article.)

pore (fp) was much larger than the accessory pore (ap) (Fig. 2H). P. concavum was encountered only at station 4 (Fig. 1).

\subsubsection{Prorocentrum cf. emarginatum (Fig. 3)}

Cells of $P$. cf. emarginatum were round to oval, slightly asymmetric and dorsoventrally flattened (Fig. 3A and B). They were 33.7-40.9 $\mu \mathrm{m}$ long (mean $37.0 \pm 1.5 \mu \mathrm{m}, n=88$ ) and 28.9-38.7 $\mu \mathrm{m}$ wide (mean $32.9 \pm 1.8 \mu \mathrm{m}, n=88$ ) with the length/width ratio varying from 1.02 to 1.24 (Table 3 ). Asexual reproduction often occurred through the hyaline division cysts (Fig. 3C). The nucleus was elongated and located in the posterior end of the cell (Fig. 3D). A presumable pyrenoid with a starch ring was situated in the cell center, with numerous chloroplasts radiating from the pyrenoid to the periphery (Fig. 3E). The thecal surface was smooth and ornamented with pores of different size (large pores with a mean diameter of $0.24 \mu \mathrm{m}$, small pores with a mean diameter of $0.11 \mu \mathrm{m}$ ), which were situated in deep depressions. The number of thecal pore was around 223 and they generally formed radial rows, but there was no pore in the center (Fig. 3F and G). Around 98 marginal pores were present. The intercalary band had transverse striations (Fig. 3I). The periflagellar area was deep, narrow, and V-shaped and consisted of nine platelets $(1,2,3,4,5,6 a, b, 7,8)$ (Fig. 3I-K). Platelet 1 had a pronounced wing, and platelets 4,7 and 8 had short lists (Fig. 3I-K). The flagella pore was much larger than the accessory pore (Fig. 3I and J). P. cf. emarginatum was encountered only at station 8 (Fig. 1).

\subsubsection{Prorocentrum fukuyoi S. Murray \& Y. Nagahama (Fig. 4)}

Cells of $P$. fukuyoi were oval to oblong, slightly asymmetric, and dorsoventrally flattened (Fig. 4A and B). They were 26.2-37.9 $\mu \mathrm{m}$ long (mean $31.4 \pm 2.4 \mu \mathrm{m}, n=94$ ) and 18.0-26.5 $\mu \mathrm{m}$ wide (mean $21.8 \pm$ $1.9 \mu \mathrm{m}, n=94$ ) with the length/width ratio varying from 1.23 to 1.57 (Table 3 ). There was a round nucleus located in the posterior end of the cell (Fig. 4C). A presumable pyrenoid with a starch ring was situated in the cell center, with numerous chloroplasts radiating from the 

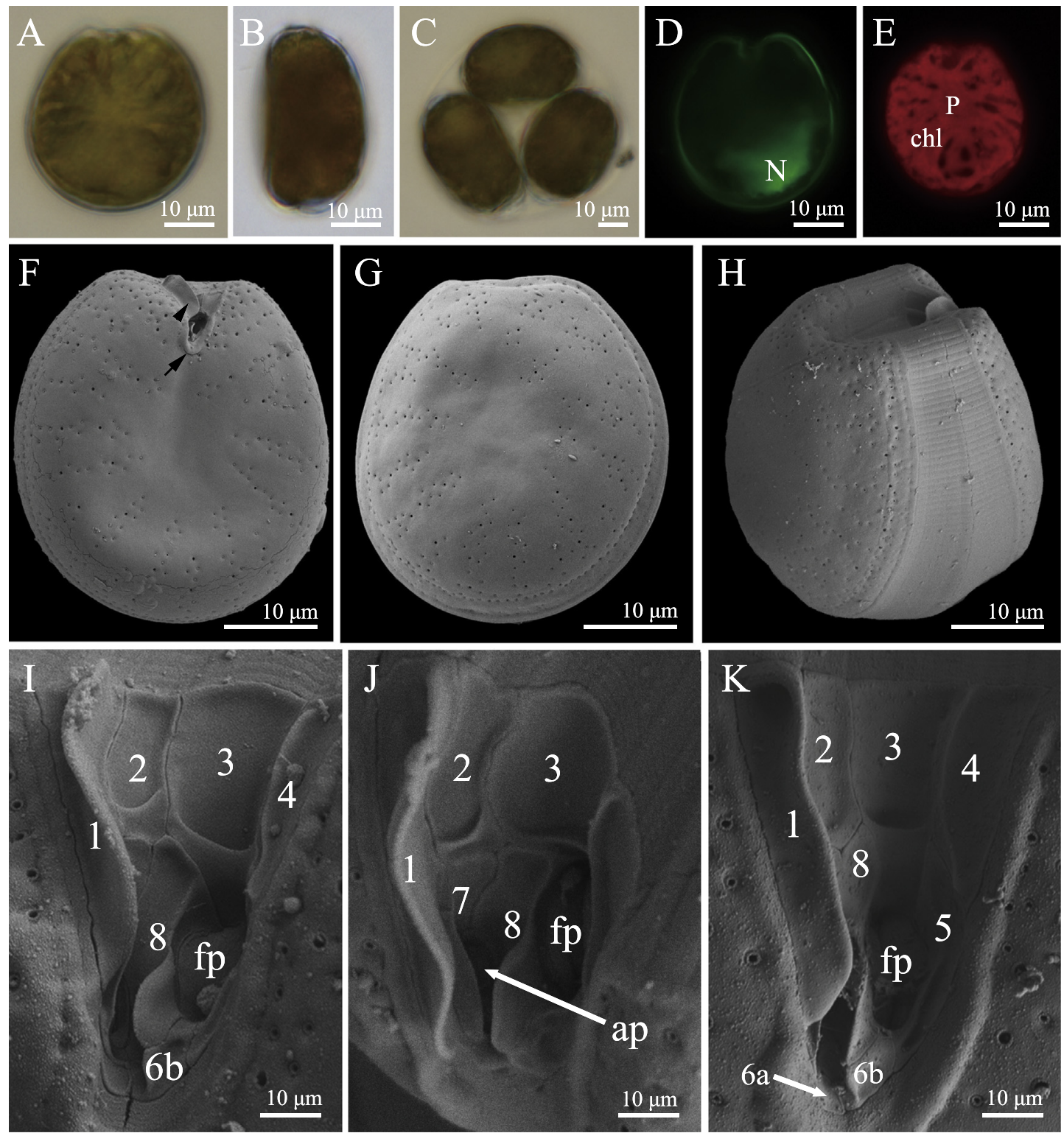

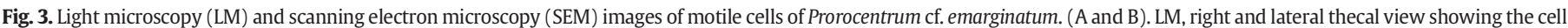

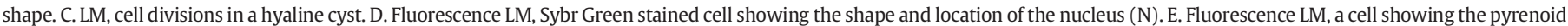

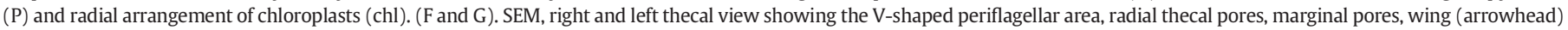

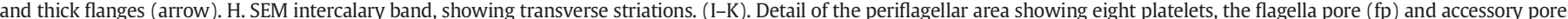
(ap). (For interpretation of the references to colour in this figure legend, the reader is referred to the web version of this article.)

Table 3

Morphological comparisons of Prorocentrum emarginatum and P. fukuyoi.

\begin{tabular}{|c|c|c|c|c|c|c|c|c|c|}
\hline & \multirow[b]{2}{*}{ Strains } & \multicolumn{3}{|l|}{ Cell size } & \multicolumn{2}{|c|}{ Number of pores } & \multicolumn{2}{|l|}{ Valve pores } & \multirow{2}{*}{ Reference } \\
\hline & & Length $(\mu \mathrm{m})$ & Width $(\mu \mathrm{m})$ & Ratio (L/W) & Valve & Marginal & $\begin{array}{l}\text { Large pores } \\
\text { diameter }(\mu \mathrm{m})\end{array}$ & $\begin{array}{l}\text { Small pores } \\
\text { diameter }(\mu \mathrm{m})\end{array}$ & \\
\hline P. emarginatum & type species & $35-36$ & 32 & $1.09-1.13$ & $100^{(?)}$ & $?$ & $0.5^{(?)}$ & $0.2^{(?)}$ & {$[24]$} \\
\hline P. cf. emarginatum & $\mathrm{X} 2 \mathrm{P} 3$ & $\begin{array}{l}33.7-40.9(37.0 \\
\pm 1.5)\end{array}$ & $\begin{array}{l}28.9-38.7(32.9 \\
\pm 1.8)\end{array}$ & $\begin{array}{l}1.02-1.24(1.13 \\
\pm 0.05)\end{array}$ & $\begin{array}{l}223 \\
\pm 20.8\end{array}$ & $\begin{array}{l}98 \\
\pm 5.6\end{array}$ & $\begin{array}{l}0.19-0.32(0.24 \\
\pm 0.03)\end{array}$ & $\begin{array}{l}0.08-0.14(0.11 \\
\pm 0.01)\end{array}$ & $\begin{array}{l}\text { Present } \\
\text { study }\end{array}$ \\
\hline P. fukuyoi & $\begin{array}{l}\text { SM19 (type } \\
\text { species) }\end{array}$ & $\begin{array}{l}28-42(38.0 \\
\pm 3.2)\end{array}$ & $\begin{array}{l}18-30(26 \\
\pm 5.5)\end{array}$ & $1.3-1.5$ & $\sim 175$ & None & $\sim 0.3$ & $\sim 0.1$ & [54] \\
\hline $\begin{array}{l}\text { P. fukuyoi (as } \\
\text { emarginatum) }\end{array}$ & SM35 & $33-36$ & $30-32$ & $1.0-1.2$ & 108 & None & $\begin{array}{l}0.18-0.25(0.22 \\
\pm 0.02)\end{array}$ & $\begin{array}{l}0.07-0.15(0.09 \\
\pm 0.01)\end{array}$ & {$[54]$} \\
\hline P. fukuyoi & NG2 & $\begin{array}{l}26.2-37.9(31.4 \\
\pm 2.4)\end{array}$ & $\begin{array}{l}18.0-26.5(21.8 \\
\pm 1.8)\end{array}$ & $\begin{array}{l}1.36-1.57(1.44 \\
\pm 0.04)\end{array}$ & $\begin{array}{l}231 \\
\pm 20.24\end{array}$ & None & $\begin{array}{l}0.30-0.39(0.34 \\
\pm 0.03)\end{array}$ & $\begin{array}{l}0.13-0.20(0.18 \\
\pm 0.01)\end{array}$ & $\begin{array}{l}\text { Present } \\
\text { study }\end{array}$ \\
\hline P. fukuyoi & TIO305 & $\begin{array}{l}26.8-34.1(30.3 \\
\pm 2.2)\end{array}$ & $\begin{array}{l}20.2-25.5(22.7 \\
\pm 1.7)\end{array}$ & $\begin{array}{l}1.23-1.37(1.32 \\
\pm 0.04)\end{array}$ & $\begin{array}{l}186 \\
\pm 19.8\end{array}$ & None & $\begin{array}{l}0.28-0.39(0.33 \\
\pm 0.02)\end{array}$ & $\begin{array}{l}0.08-0.20(0.13 \\
\pm 0.04)\end{array}$ & $\begin{array}{l}\text { Present } \\
\text { study }\end{array}$ \\
\hline
\end{tabular}

?:questionable 

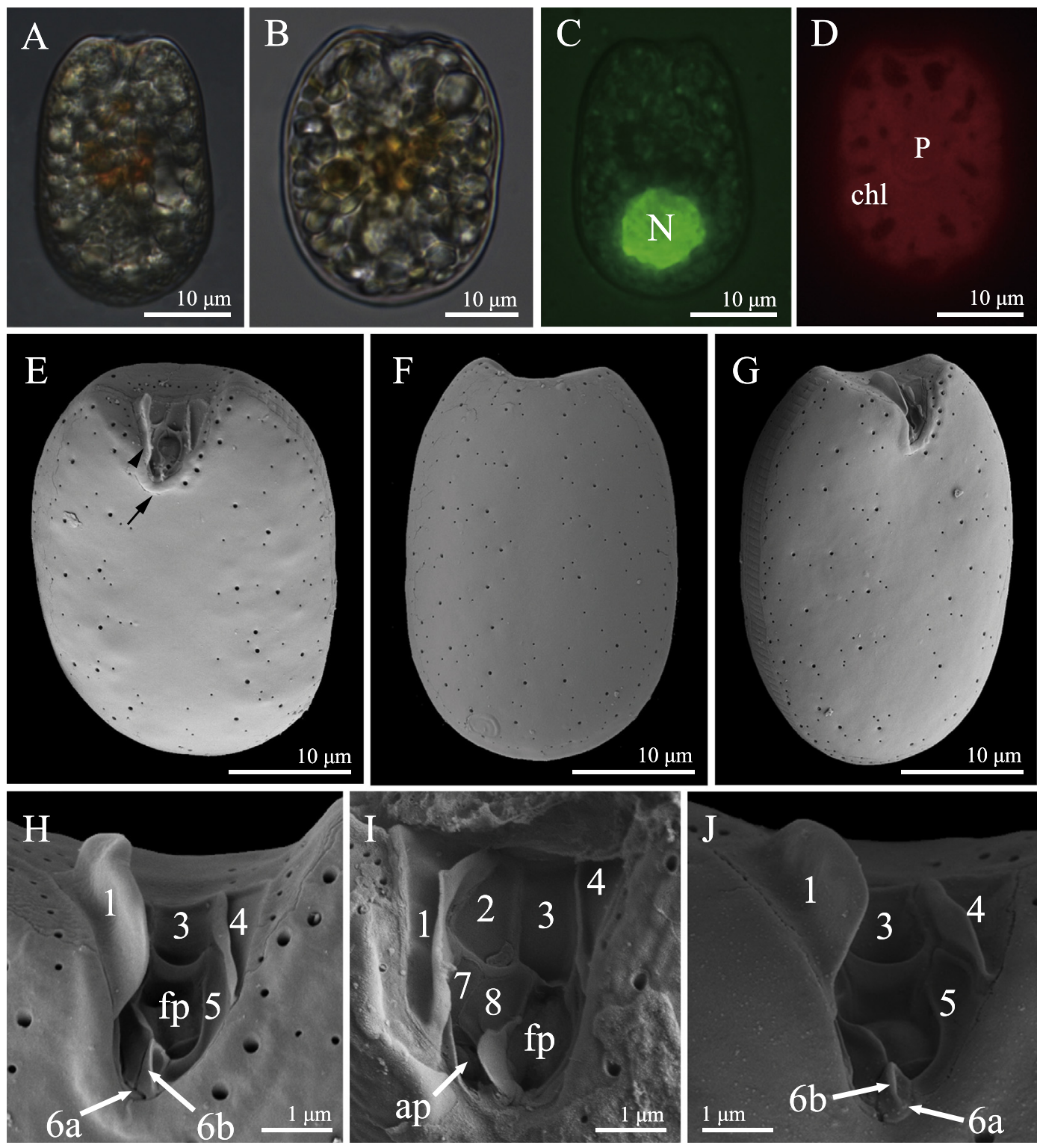

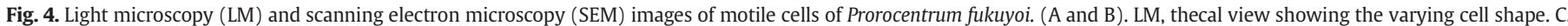

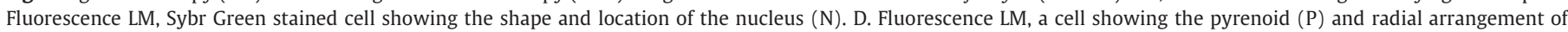

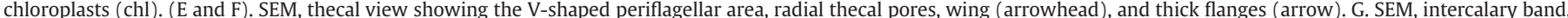

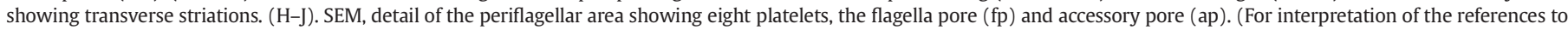
colour in this figure legend, the reader is referred to the web version of this article.)

pyrenoid to the periphery (Fig. 4D). The thecal plate was smooth and ornamented with pores of different size (large pores with a diameter of $0.28-0.39 \mu \mathrm{m}$; small pores with a diameter of $0.08-0.20 \mu \mathrm{m})$. The number of thecal pores was around 200 and they formed radial rows, but there were no pores in the central part of the cell and neither any marginal pore (Fig. 4E-G). The intercalary band had transverse striations (Fig. 4G). The periflagellar area was deep, narrow, and V-shaped consisting of nine platelets $(1,2,3,4,5,6 \mathrm{a}, \mathrm{b}, 7,8)$ (Fig. 4H-J). Platelet 1 had a pronounced wing, and platelets 4,7 and 8 had short lists (Fig. $4 \mathrm{H}-\mathrm{J}$ ). The flagella pore was much larger than the accessory pore (Fig. 4H and I). P. fukuyoi was encountered at stations 4 and 10 (Fig. 1).

\subsubsection{Prorocentrum lima (Ehrenberg) F. Stein (Fig. 5)}

Synonym: Prorocentrum arenarium Faust

Cells of $P$. lima were oval, symmetric, and dorsoventrally flattened (Fig. 5A and B). They were 37.6-45.3 $\mu \mathrm{m}$ long and 26.4-30.5 $\mu \mathrm{m}$ wide with the length/width ratio varying from 1.39 to 1.58 (Table 4). Cells reproduced through binary fission (Fig. 5B). There was an elongated nucleus located in the posterior end of the cell (Fig. 5C). A pyrenoid with a starch ring was situated in the cell center, with numerous chloroplasts radiating from the pyrenoid to the periphery (Fig. 5D). The thecal plate was smooth and ornamented with round to elongated pores (0.20-0.59 $\mu \mathrm{m}$ long, $0.14-0.43 \mu \mathrm{m}$ wide). The number of pores varied from 56 to 66 , but pores were absent in the central part of the cell (Fig. 5E-G). Around 56-65 marginal row pores were observed (Fig. 5F and $G$ ). The intercalary band had transverse striations (Fig. 5G). The periflagellar area was wide $\mathrm{V}$-shaped, consisting of eight platelets $(1,2,3,4,5,6,7,8)$ (Fig. 5H and I). P. lima was encountered at stations 2 and 9 (Fig. 1).

\subsubsection{Prorocentrum cf. maculosum (Fig. 6)}

Cells of $P$. cf. maculosum were oval to ovoid, symmetric, and dorsoventrally flattened (Fig. 6A and B). They were 38.7-51.7 $\mu \mathrm{m}$ long, 26.1-39.9 $\mu \mathrm{m}$ wide, with the length/width ratio varying from 1.18 to 1.55 (Table 4). Cells reproduced through binary fission (Fig. 6B). The elongated nucleus was located in the posterior end of the cell 

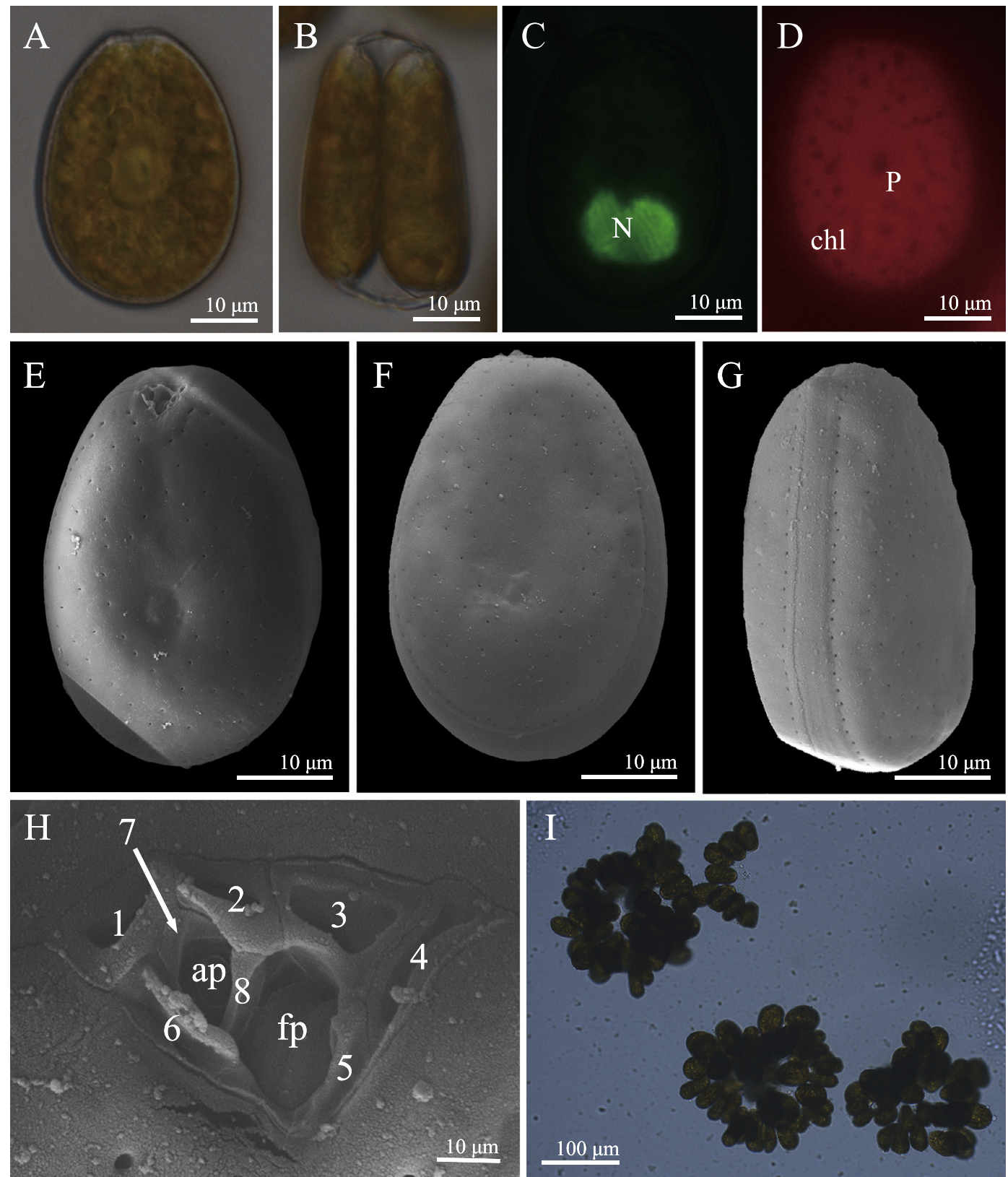

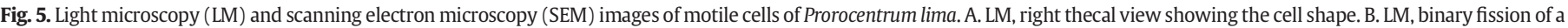

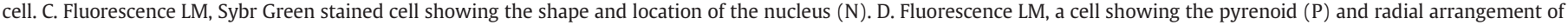

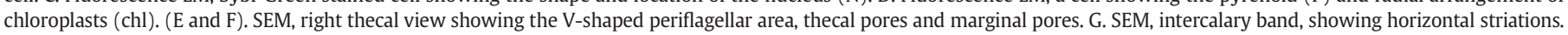

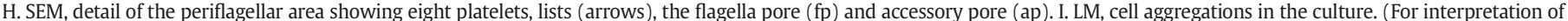
the references to colour in this figure legend, the reader is referred to the web version of this article.)

(Fig. 6C). A pyrenoid with a starch ring was situated in the cell center, with numerous chloroplasts radiating from the pyrenoid to the periphery (Fig. 6D). The thecal surface was smooth and ornamented with oblong or kidney-shaped pores $(0.39-0.86 \mu \mathrm{m}$ long, $0.18-0.51 \mu \mathrm{m}$ wide) (Fig. $6 \mathrm{E}-\mathrm{G}$ ). The valve pore number varied from 59 to 79 and there were 51-66 marginal pores (Table 4). There was no pore in the central part of the cell (Fig. 6E and F). The intercalary band had transverse striation (Fig. 6I). The periflagellar area was wide V-shaped, and consisted of eight platelets $(1,2,3,4,5,6,7,8)$ (Fig. 6E and F). P. cf. maculosum was encountered at stations 5, 6, 7 and 9 (Fig. 1).

\subsubsection{Prorocentrum panamense Grzebyk, Sako E' Berland (Fig. 7)}

Cells of $P$. panamense were heart-shaped and asymmetric (Fig. 7A). They were 52.3-55.6 $\mu \mathrm{m}$ long (mean $54.1 \pm 1.0 \mu \mathrm{m}, n=50$ ) and 48.3-50.7 $\mu \mathrm{m}$ wide (mean $49.4 \pm 1.0 \mu \mathrm{m}, n=50$ ) with the length/width ratio varying from 1.06 to 1.13 . The U-shaped nucleus was located in the posterior end of the cell (Fig. 7B). A pyrenoid with a starch ring was situated in the cell center, with numerous chloroplasts radiating from the pyrenoid to the periphery (Fig. 7A and $\mathrm{C}$ ). The thecal plates were reticulate-foveate but the depressions in the center were much shallower. There were round pores with a diameter of $0.07-0.13 \mu \mathrm{m}$ located inside the depressions. There was a large pore (around $1.4 \mu \mathrm{m}$ in diameter) nearby the margin in the right thecal plate (Fig. 7D). The periflagellar area was linear consisting of nine strongly reticulate-foveate platelets $(1,2,3,4,5$, $6 a, b, 7,8$ ) (Fig. 7D and E). The intercalary band had transverse striation (Fig. 7F). P. panamense was encountered only at station 6 (Fig. 1). 
Table 4

Morphological comparisons of Prorocentrum lima and P. maculosum.

\begin{tabular}{|c|c|c|c|c|c|c|c|c|c|c|}
\hline & \multirow[b]{2}{*}{ Strains } & \multicolumn{3}{|l|}{ Cell size } & \multicolumn{2}{|c|}{ Number of pores } & \multicolumn{3}{|l|}{ Valve pores } & \multirow[b]{2}{*}{ Reference } \\
\hline & & Length $(\mu \mathrm{m})$ & Width $(\mu \mathrm{m})$ & Ratio (L/W) & Valve & Marginal & Length $(\mu \mathrm{m})$ & Width $(\mu \mathrm{m})$ & Ratio (L/W) & \\
\hline P. lima & $\begin{array}{l}\text { Type } \\
\text { species }\end{array}$ & 36 & 27 & 1.33 & 65 & 62 & 0.37 & 0.37 & 1 & [56] \\
\hline P. lima & TIO124 & $\begin{array}{l}40.1-45.3(42.8 \\
\pm 1.2)\end{array}$ & $\begin{array}{l}26.6-30.5(29.2 \\
\pm 1.2)\end{array}$ & $\begin{array}{l}1.40-1.58(1.47 \\
\pm 0.06)\end{array}$ & $\begin{array}{l}66 \\
\pm 4.9\end{array}$ & $\begin{array}{l}57 \\
\pm 1.2\end{array}$ & $\begin{array}{l}0.31-0.46(0.36 \\
\pm 0.04)\end{array}$ & $\begin{array}{l}0.22-0.43(0.32 \\
\pm 0.04)\end{array}$ & $\begin{array}{l}1.0-1.8(1.2 \\
\pm 0.2)\end{array}$ & $\begin{array}{l}\text { Present } \\
\text { study }\end{array}$ \\
\hline P. lima & TI0155a & $\begin{array}{l}39.2-41.3(40.5 \\
\pm 1.1)\end{array}$ & $\begin{array}{l}26.4-28.3(27.6 \\
\pm 0.9)\end{array}$ & $\begin{array}{l}1.45-1.48(1.46 \\
\pm 0.02)\end{array}$ & $\begin{array}{l}61 \\
\pm 7.8\end{array}$ & $\begin{array}{l}65 \\
\pm 4.6\end{array}$ & $\begin{array}{l}0.20-0.33(0.26 \\
\pm 0.04)\end{array}$ & $\begin{array}{l}0.20-0.33(0.26 \\
\pm 0.04)\end{array}$ & $1.0 \pm 0.1$ & $\begin{array}{l}\text { Present } \\
\text { study }\end{array}$ \\
\hline P. lima & TI0163 & $\begin{array}{l}37.6-42.6(40.4 \\
\pm 2.3)\end{array}$ & $\begin{array}{l}26.5-28.5(27.4 \\
\pm 0.9)\end{array}$ & $\begin{array}{l}1.42-1.50(1.47 \\
\pm 0.05)\end{array}$ & $\begin{array}{l}65 \\
\pm 1.0\end{array}$ & $\begin{array}{l}57 \\
\pm 1.2\end{array}$ & $\begin{array}{l}0.20-0.36(0.29 \\
\pm 0.05)\end{array}$ & $\begin{array}{l}0.14-0.24(0.21 \\
\pm 0.02)\end{array}$ & $\begin{array}{l}1.0-2.5(1.4 \\
\pm 0.4)\end{array}$ & $\begin{array}{l}\text { Present } \\
\text { study }\end{array}$ \\
\hline P. lima & TI0162 & $\begin{array}{l}41.3-42.7(41.8 \\
\pm 0.4)\end{array}$ & $\begin{array}{l}27.3-28.7(27.9 \\
\pm 0.4)\end{array}$ & $\begin{array}{l}1.47-1.53(1.49 \\
\pm 0.01)\end{array}$ & $\begin{array}{l}62 \\
\pm 4.2\end{array}$ & $\begin{array}{l}56 \\
\pm 2.7\end{array}$ & $\begin{array}{l}0.26-0.47(0.36 \\
\pm 0.04)\end{array}$ & $\begin{array}{l}0.17-0.35(0.24 \\
\pm 0.03)\end{array}$ & $\begin{array}{l}1.0-2.1(1.5 \\
\pm 0.3)\end{array}$ & $\begin{array}{l}\text { Present } \\
\text { study }\end{array}$ \\
\hline P. lima & TIO302 & $\begin{array}{l}41.2-43.5(42.2 \\
\pm 0.6)\end{array}$ & $\begin{array}{l}28.7-30.5(29.6 \\
\pm 0.4)\end{array}$ & $\begin{array}{l}1.39-1.48(1.43 \\
\pm 0.02)\end{array}$ & $\begin{array}{l}56 \\
\pm 4.6\end{array}$ & $\begin{array}{l}59 \\
\pm 5.4\end{array}$ & $\begin{array}{l}0.32-0.59(0.46 \\
\pm 0.05)\end{array}$ & $\begin{array}{l}0.21-0.36(0.26 \\
\pm 0.03)\end{array}$ & $\begin{array}{l}1.3-2.1(1.7 \\
\pm 0.2)\end{array}$ & $\begin{array}{l}\text { Present } \\
\text { study }\end{array}$ \\
\hline $\begin{array}{l}P . \\
\text { maculosum }\end{array}$ & $\begin{array}{l}\text { Type } \\
\text { species }\end{array}$ & $40-50$ & $30-40$ & NA & $85-90$ & $65-75$ & 0.6 & $0.27 \pm 0.05$ & $2.2 \pm 0.4$ & [20] \\
\hline $\begin{array}{l}\text { P. cf. } \\
\text { maculosum }\end{array}$ & TIO11 & $\begin{array}{l}40.5-46.5(43.7 \\
\pm 1.7)\end{array}$ & $\begin{array}{l}33.5-37.5(35.5 \\
\pm 1.1)\end{array}$ & $\begin{array}{l}1.18-1.29(1.23 \\
\pm 0.03)\end{array}$ & $\begin{array}{l}79 \\
\pm 5.0\end{array}$ & $\begin{array}{l}58 \\
\pm 3.0\end{array}$ & $\begin{array}{l}0.55-0.86(0.74 \\
\pm 0.07)\end{array}$ & $\begin{array}{l}0.29-0.51(0.42 \\
\pm 0.04)\end{array}$ & $\begin{array}{l}1.3-2.6(1.8 \\
\pm 0.3)\end{array}$ & $\begin{array}{l}\text { Present } \\
\text { study }\end{array}$ \\
\hline $\begin{array}{l}\text { P. cf. } \\
\text { maculosum }\end{array}$ & TI0102 & $\begin{array}{l}47.7-51.7(49.2 \\
\pm 1.5)\end{array}$ & $\begin{array}{l}38.1-39.9(39.0 \\
\pm 0.8)\end{array}$ & $\begin{array}{l}1.24-1.30(1.26 \\
\pm 0.03)\end{array}$ & $\begin{array}{l}85 \\
\pm 2.6\end{array}$ & $\begin{array}{l}66 \\
\pm 6.4\end{array}$ & $\begin{array}{l}0.57-0.85(0.67 \\
\pm 0.06)\end{array}$ & $\begin{array}{l}0.30-0.43(0.35 \\
\pm 0.04)\end{array}$ & $\begin{array}{l}1.7-2.3(1.9 \\
\pm 0.2)\end{array}$ & $\begin{array}{l}\text { Present } \\
\text { study }\end{array}$ \\
\hline $\begin{array}{l}\text { P. cf. } \\
\text { maculosum }\end{array}$ & TI0138 & $\begin{array}{l}41.3-42.7(43.0 \\
\pm 0.8)\end{array}$ & $\begin{array}{l}28.2-30.8(30.0 \\
\pm 0.7)\end{array}$ & $\begin{array}{l}1.37-1.48(1.43 \\
\pm 0.03)\end{array}$ & $\begin{array}{l}59 \\
\pm 9.0\end{array}$ & $\begin{array}{l}51 \\
\pm 3.3\end{array}$ & $\begin{array}{l}0.39-0.78(0.56 \\
\pm 0.08)\end{array}$ & $\begin{array}{l}0.23-0.45(0.31 \\
\pm 0.04)\end{array}$ & $\begin{array}{l}1.2-3.2(1.8 \\
\pm 0.4)\end{array}$ & $\begin{array}{l}\text { Present } \\
\text { study }\end{array}$ \\
\hline $\begin{array}{l}\text { P. cf. } \\
\text { maculosum }\end{array}$ & TI0179 & $\begin{array}{l}38.7-42.4(41.1 \\
\pm 1.1)\end{array}$ & $\begin{array}{l}27.4-29.1(28.5 \\
\pm 0.6)\end{array}$ & $\begin{array}{l}1.33-1.54(1.45 \\
\pm 0.05)\end{array}$ & $\begin{array}{l}67 \\
\pm 2.3\end{array}$ & $\begin{array}{l}53 \\
\pm 4.5\end{array}$ & $\begin{array}{l}0.43-0.73(0.57 \\
\pm 0.06)\end{array}$ & $\begin{array}{l}0.20-0.39(0.29 \\
\pm 0.04)\end{array}$ & $\begin{array}{l}1.3-3.3(2.4 \\
\pm 0.4)\end{array}$ & $\begin{array}{l}\text { Present } \\
\text { study }\end{array}$ \\
\hline $\begin{array}{l}\text { P. cf. } \\
\text { maculosum }\end{array}$ & TIO180 & $\begin{array}{l}39.1-42.6(40.4 \\
\pm 1.2)\end{array}$ & $\begin{array}{l}26.1-28.3(27.4 \\
\pm 0.8)\end{array}$ & $\begin{array}{l}1.41-1.55(1.47 \\
\pm 0.06)\end{array}$ & $\begin{array}{l}66 \\
\pm 3.4\end{array}$ & $\begin{array}{l}58 \\
\pm 1.1\end{array}$ & $\begin{array}{l}0.52-0.67(0.59 \\
\pm 0.07)\end{array}$ & $\begin{array}{l}0.18-0.26(0.21 \\
\pm 0.02)\end{array}$ & $\begin{array}{l}2.2-3.5(2.8 \\
\pm 0.3)\end{array}$ & $\begin{array}{l}\text { Present } \\
\text { study }\end{array}$ \\
\hline
\end{tabular}

3.1.7. Prorocentrum rhathymum A.R. Loeblich III, Sherley \&'Schmidt (Fig. 8) Cells of $P$. rhathymum were oval to oblong and asymmetric (Fig. 8A). They were 31.0-33.5 $\mu \mathrm{m}$ long (mean $32.0 \pm 0.8 \mu \mathrm{m}, n=50$ ) and 23.6$26.9 \mu \mathrm{m}$ wide (mean $24.9 \pm 1.2 \mu \mathrm{m}, n=50$ ) with the length/width ratio varying from 1.21 to 1.34 . The cells reproduced by binary fission (Fig. 8B). The elongated nucleus was located in the posterior end of the cell (Fig. 8C). A presumable pyrenoid with a starch ring was situated in the cell center, with numerous chloroplasts radiating from the pyrenoid to the periphery (Fig. 8D). The thecal plates were foveate and ornamented by around 120 pores of two sizes. The large pores were $0.36-0.50 \mu \mathrm{m}$ in diameter, whereas the small pores were 0.09 $0.14 \mu \mathrm{m}$ in diameter. They formed radial rows, especially in the anterior and posterior part of the cell (Fig. 8E and F). The intercalary band had transverse striation (Fig. 8G). The periflagellar area was wide $\mathrm{V}$-shaped consisting of nine platelets $(1,2,3,4,5,6 \mathrm{a}, \mathrm{b}, 7,8)$ (Fig. 8E, H-I). Platelet 1 had a pronounced wing like spine (Fig. $8 \mathrm{~A}$ and $\mathrm{E}$ ). P. rhathymum was encountered at stations 1, 3, 5, 6 and 7 (Fig. 1).

A schematic graphic was presented to show cell shape, periflagellar area, the pore pattern and patterns of periflagellar platelets of all investigated species (Fig. 9).

\subsection{Molecular phylogeny}

For LSU sequences comparison, the four Chinese $P$. concavum strains shared identical sequences, but they differed from the Reunion Island strain PCRN01, Malaysia strain NMN103, and Arabian Sea strain CCMP1724 at 13, 17, and 17 positions (98.5\%, 98.8\% and 98.8\% similarity), respectively. Chinese $P$. cf. emarginatum strain X2P3 differed from Reunion Island strain PCRN05 and strain PES401 (origin not available) at 15 and 21 positions (98.2\% and 98.4\% similarity), respectively, and from P. sculptile Faust strain NMN011 at 20 positions (98.5\% similarity). Chinese P. fukuyoi strain TIO309 differed from Arabian Gulf strain IFR10311, Japanese strain SM39, German strain IFR11-188, and French strain IFR $11-234$ at $28,32,60$, and 56 positions (97.2\%, 97.3\%, 94.0\%, and $93.6 \%$ similarity), respectively.

Chinese $P$. lima strains differed from each other at 3-6 positions (99.6\%-99.8\% similarity) and strain TIO124 differed from Australia strain SM24, SM29 and Italy strain Sorrento 1 at 2, 22, and 47 positions (99.9\%, 98.4\%, and 96.7\% similarity), respectively. Chinese $P$. cf. maculosum strains differed from each other at 1 to 10 positions (99.3\%-99.9\% similarity) and strain TIO179 differed from Cuba strain PMHV-1 at 6 positions (99.5\% similarity). P. panamense strain TIO97 differed from Martinique Island strain IFR12-218 at 2 positions $(99.7 \%$ similarity). Chinese P. rhathymum strains and Korea strain PRJJ1 shared identical LSU sequences, but they differed from Australia strain PRHI01 at 2 positions (99.7\% similarity).

Maximum likelihood (ML) and Bayesian inference (BI) based on LSU sequences generated similar trees that differed only in a few topologies. One of the trees is illustrated in Fig. 10. Prorocentrum species were classified into two clades. One clade contained mainly planktonic species, but it also included asymmetrical benthic species such as $P$. emarginatum, P. fukuyoi and P. rhathymum. The other clade included symmetrical benthic species, e.g., P. panamense, P. lima, P. maculosum and $P$. concavum.

$P$. emarginatum and $P$. sculptile grouped together with maximal support (ML bootstrap support values: 100; Bayesian posterior probabilities: 1.0), and they were a sister clade of $P$. fukuyoi with maximal support. P. rhathymum grouped together with planktonic species (e.g. P. koreanum M. S. Han, S. Y. Cho \& P. Wang, $P$. micans and $P$. gracile Schütt) with maximal support. P. lima was monophyletic consisting of three subclades with maximal support. P. maculosum was monophyletic too, and it was a sister clade of $P$. hoffmannianum/P. belizeanum. They formed a sister clade of $P$. lima with maximal support. $P$. concavum, $P$. foraminosum M. A. Faust and P. levis formed a well resolved group with maximal support, and $P$. panamense and $P$. glenanicum Chomérat \& Nézan also formed a well resolved group with maximal support.

Maximum likelihood (ML) and Bayesian inference (BI) based on ITS sequences generated similar trees that differed only in a few topologies. One of the trees is illustrated in Fig. 11, which is consistent with the phylogeny based on LSU sequences.

\subsection{Okadaic acid and dinophysistoxin concentrations}

Nine strains of $P$. lima, 6 strains each of $P$. cf. maculosum and $P$. rhathymum, 2 strains of $P$. concavum, and 1 strain of $P$. panamense were subjected to toxin analysis. All strains of $P$. lima and $P$. cf. maculosum produced OA at levels ranging from 551 to $10,260 \mathrm{fg}$ cell $^{-1}$. Two strains of $P$. lima also produced DTX-1 at 910 and $1810 \mathrm{fg}^{-1}$ cell $^{-1}$. Other species did not produce detectable level of OA (Table 1). 

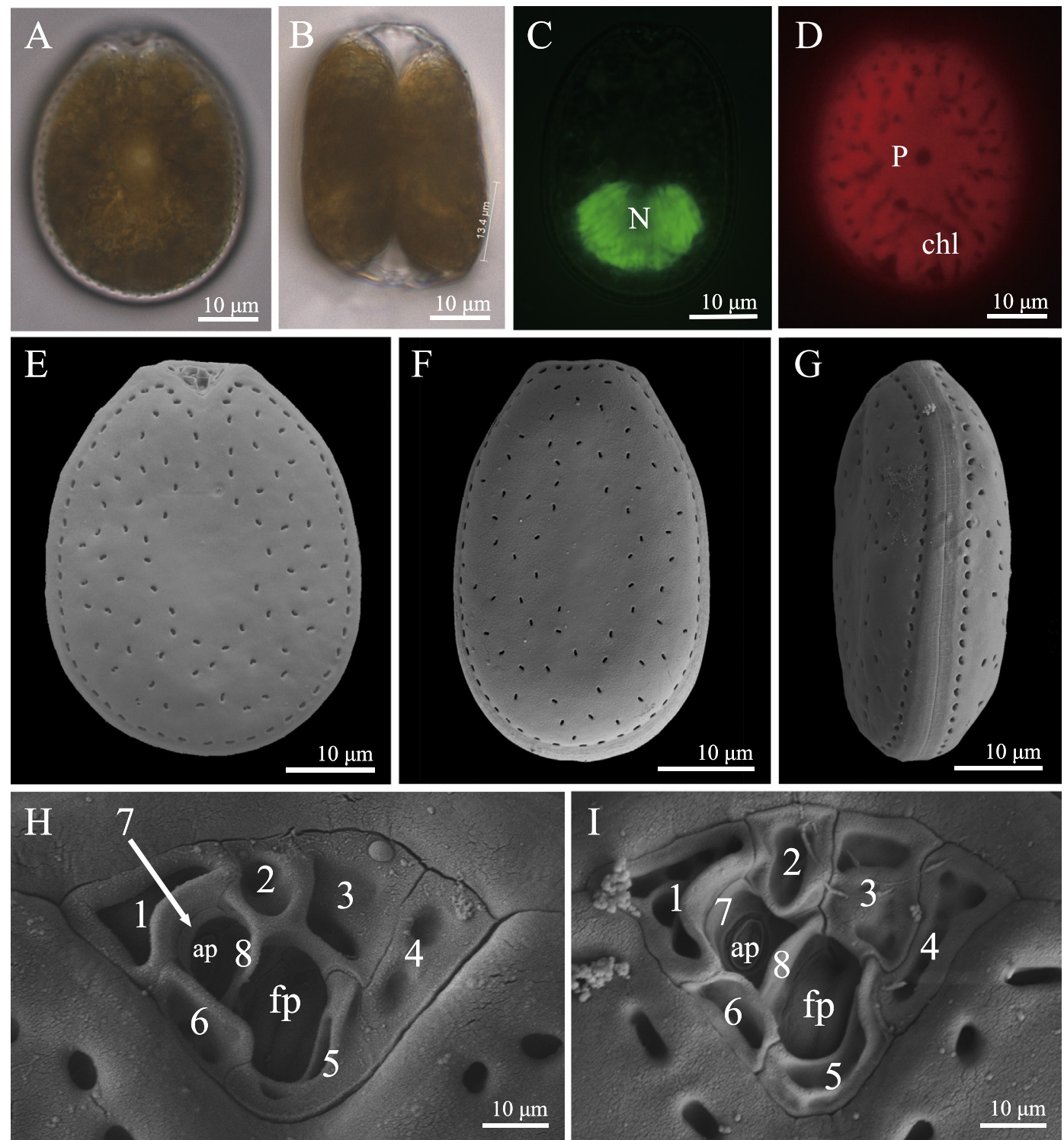

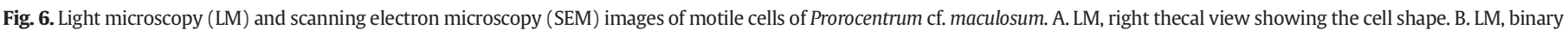

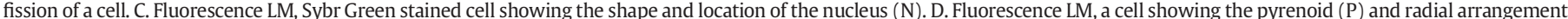

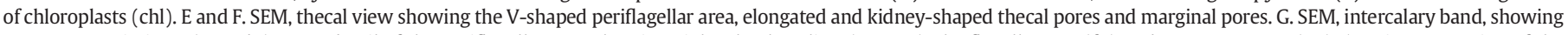

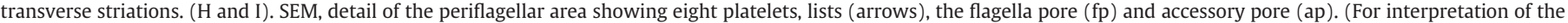
references to colour in this figure legend, the reader is referred to the web version of this article.)

\section{Discussion}

\subsection{Morphology and biogeography}

\subsubsection{P. concavum}

Chinese $P$. concavum is consistent with the original description regarding the wide V-shaped periflagellar area, with a much larger fp relative to ap [24,48]. However, the Chinese strains exhibit variability of platelet 1 in the periflagellar area (i.e., one platelet or divisions $1 \mathrm{a}$ and $1 \mathrm{~b}$, whereas the Malaysian strain always shows the division of platelet 1 [48]. P. foraminosum also has a wide V-shaped periflagellar area and numerous depressions, but it differs from $P$. concavum in the divisions of platelet $6(6 a, 6 b)[20]$.

P. concavum was described from French Polynesia, New Caledonia and the Ryukyu Islands [24], and was reported to occur in the Gulf of Oman, Arabian Sea (as P. arabianum) [50], Sabah, Malaysia [48], Gulf of Panama [25], and northern South China Sea (present study), suggesting that it has a wide geographic distribution.

\subsubsection{P. emarginatum and P. fukuyoi}

P. emarginatum and $P$. fukuyoi share a narrow V-shaped periflagellar area and thecal pores with radial patterns. P. emarginatum was described from the Rikuyo Islands based on light microscopy results only and its morphological details are not available [24]. Therefore, we identified the Chinese specimens as $P$. cf. emarginatum tentatively. P. fukuyoi was described from Sydney, Australia, and it differs from P. emarginatum mainly in valve shape, and in having protrusions in the apical region [54]. However, the "P. emarginatum" strain SM35 used for comparison was isolated from Fiji and the main difference between these species is the length/width ratio [54]. The length/width ratio can be variable in Prorocentrum species, such as P. lima [56] and P. fukuyoi (Fig. 4). In the original description of $P$. fukuyoi, the ap was not reported probably because it was masked by the apical flange [54]. Hoppenrath et al. [33] provided a line drawing of the periflagellar platelets of $P$. fukuyoi (Fig. 7) which showed a small ap, as was also found in the Chinese strain (Fig. 4I). Hoppenrath et al. [33] also provided a line drawing of the periflagellar platelets of $P$. emarginatum (Fig. 7), on which ap was 

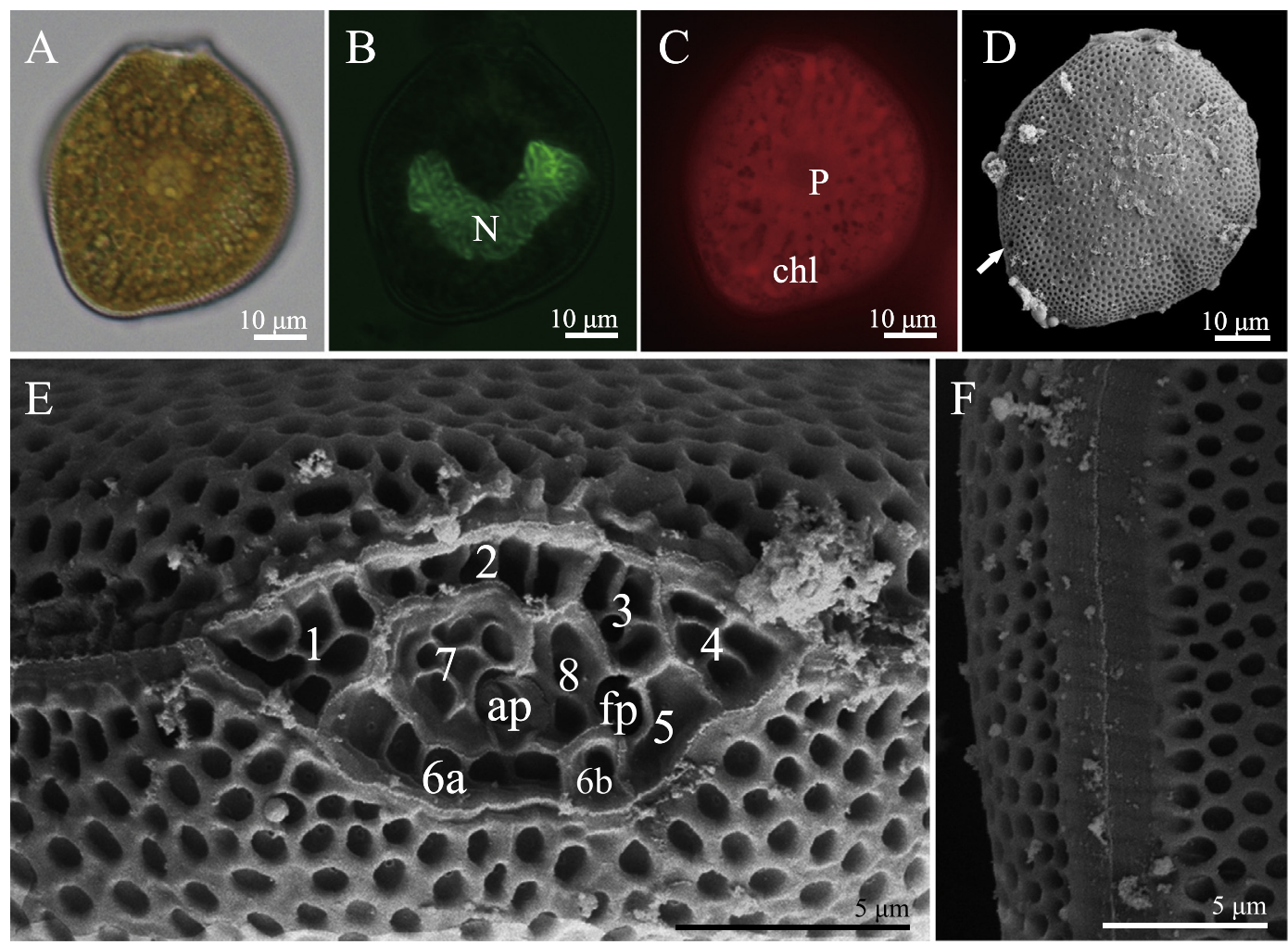

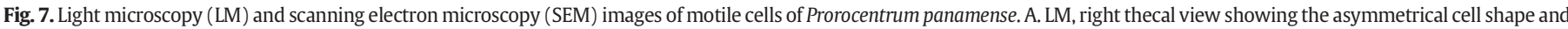

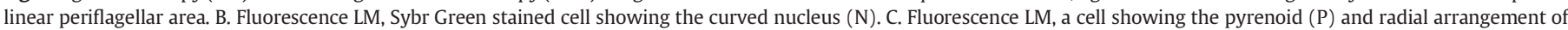

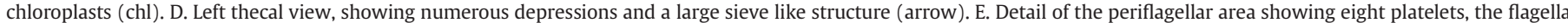

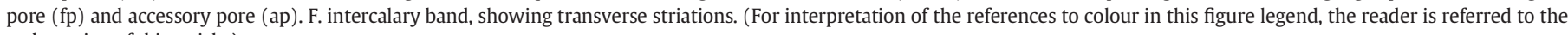
web version of this article.)

absent. However, Chinese P. emarginatum have a small ap, similar to that of $P$. fukuyoi. Moreover, $P$. fukuyoi and P. emarginatum share pores of different sizes with a radial pattern and division cysts. The major difference between these two species might be that $P$. emarginatum has marginal pores (Fig. 3J) but P. fukuyoi does not (Table 3). If this is true, $P$. emarginatum reported from Belize and Fiji might be $P$. fukuyoi instead [18,54], whereas those from Sabah are P. emarginatum [47]. This issue will not be clarified until $P$. emarginatum from the type locality is examined in detail.

\subsubsection{P. lima and P. maculosum}

P. lima from the South China Sea generally fit the original description from the type locality [56]. They have round to elongated valve pores, a $\mathrm{V}$-shaped periflagellar area, and a large fp that is about twice the size of ap (Fig. 5). The length/width ratio of Chinese P. lima is variable, as previously reported [57]. Chinese $P$. cf. maculosum strains have large kidney-shaped valve pores, which is characteristic of this species [20]. However, the Chinese strains have a smooth thecal surface in contrast to the rugose surface in the original descriptions [20]. The length/ width ratio of $P$. maculosum is variable, suggesting that this is not a reliable feature for differentiation at the species level. The fp is equal to ap in size in the original description [20], but fp is slightly larger in the Chinese strains. The ridge in the intercalary band of $P$. maculosum [20] was not observed in the Chinese strains. Due to these differences, we identified the Chinese strains as $P$. cf. maculosum. Cells of P. maculosum are evenly distributed in culture whereas cells of $P$. lima tend to aggregate. Previously, cell aggregation was only reported in P. levis [3], and the underlying mechanism for this behavior is not clear. This unusual character might help to differentiate $P$. maculosum from $P$. lima.

$P$. lima is a cosmopolitan species [57], whereas P. maculosum has only been reported in Central America, including Belize, Panama, Cuba, and the British Virgin Islands [20,25,30,75]. Some P. lima specimens were reported to have kidney-shaped pores, such as morphotypes 4 and 5 from the South China Sea [74] and specimens from Greece (Fig. 6H in [3]); these specimens might be P. maculosum instead.

\subsubsection{P. panamense}

The Chinese strain of $P$. panamense was characterized by strong depressions with pores inside, asymmetrical cell shape, and a sieve-like structure, which fit the original description of $P$. panamense [25]. It differs from P. pseudopanamense Chomérat E Nézan, which is not heartshaped [11]. P. panamense was previously reported in the Gulf of Panama, which is located in the tropical east Pacific [25], so its presence in the South China Sea extends its distribution to the subtropical western Pacific.

\subsubsection{Prorocentrum rhathymum}

P. rhathymum was characterized by a small anterior spine and posterior radial thecal pores [43]. Cortes-Altamirano and Sierra-Beltran [12] argued that $P$. rhathymum is an epibenthic species and $P$. mexicanum is a planktonic one. However, P. rhathymum was described from a plankton sample and in the molecular phylogeny they are not separate, suggesting that they might be conspecific. P. rhyathymum was reported in Okinawa, Japan [24], Greece [3], Mexico [4], Malaysia [47], Kuwait [62] and China (present study).

\subsection{Molecular phylogeny}

In the molecular phylogeny, one clade incorporates only benthic and symmetrical species, and the other includes both planktonic and benthic species; this finding, supports the premise that the benthic state might have evolved several times [53]. Our results also support the belief that the shape of the periflagellar area is phylogenetically significant [33]. Those species sharing a linear periflagellar area ( $P$. panamense, $P$. 

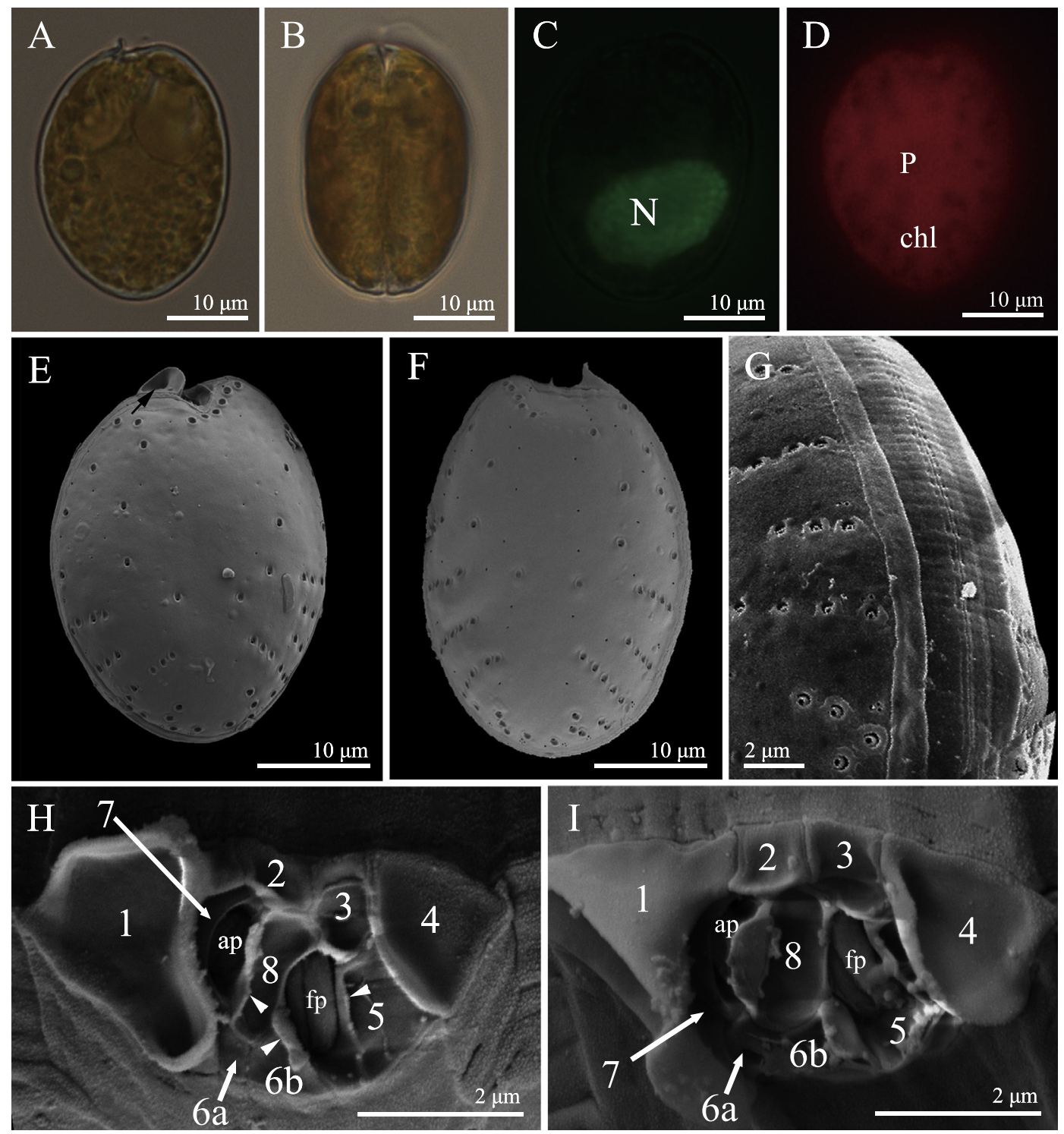

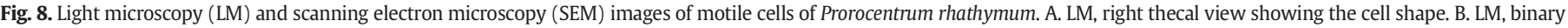

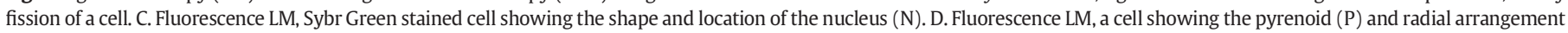

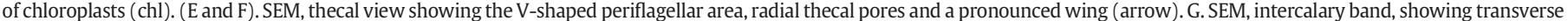

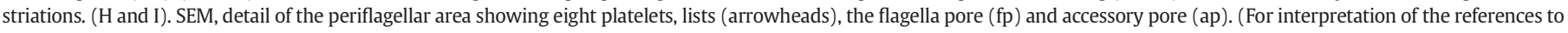
colour in this figure legend, the reader is referred to the web version of this article.)

glenanicum and P. pseudopanamense) form a well-resolved clade ([11, 25]; present study). Additionally, those species sharing a deep, narrow periflagellar area (P. emarginatum, $P$. fukuyoi and $P$. sculptile) group together. The systematic importance of other parts of the periflagellar area (e.g., the relative size of fp and ap, division of platelets) remain to be determined.

Our results suggest that the presence/absence of marginal pores might be the key feature for separating P. emarginatum from P. fukuyoi, but more information about $P$. emarginatum from the type locality is needed. $P$. sculptile differs from $P$. emarginatum and $P$. fukuyoi by possessing numerous depressions [21]. The single available LSU rDNA sequence of $P$. sculptile is highly similar to that of $P$. emarginatum, suggesting that they might be conspecific. However, sequences of $P$. sculptile from the type locality are not available and will be the focus of future study.

Chinese P. lima share $97 \%$ similarity of LSU sequences with that from the type locality, and all of them form a monophyletic clade. They are scattered into three subclades (Fig. 10), as also reported previously based on SSU rDNA sequences [57] and based on ITS sequences
(Fig. 11). Our results support the idea that P. lima might contain several cryptic species [57]. In contrast, Chinese P. cf. maculosum share $99.5 \%$ similarity of LSU sequences with that from the type locality, suggesting that the presence and number of depressions might be plastic and not suitable for differentiation at the species level. Strain K-0625 from Indonesia was designated as P. lima [48] but it is nested within $P$. maculosum, and it might have been misidentified. The close relationship between $P$. maculosum and P. hoffmannianum suggests that they might be conspecific, but support for this premise will require more evidence from material collected in Belize.

\subsection{Toxin profiles}

OA was reported in $P$. concavum [14,35], but the corresponding cells have numerous depressions and might be $P$. hoffmannianum instead [33]. P. concavum from Okinawa, Japan showed strong ichthyotoxicity but did not produce detectable OA [72]. P. concavum from the Gulf of Oman (as P. arabianum) produced a cytotoxic and ichthyotoxic compound, but OA production was not observed [50]. Our results suggest 
P. concavum
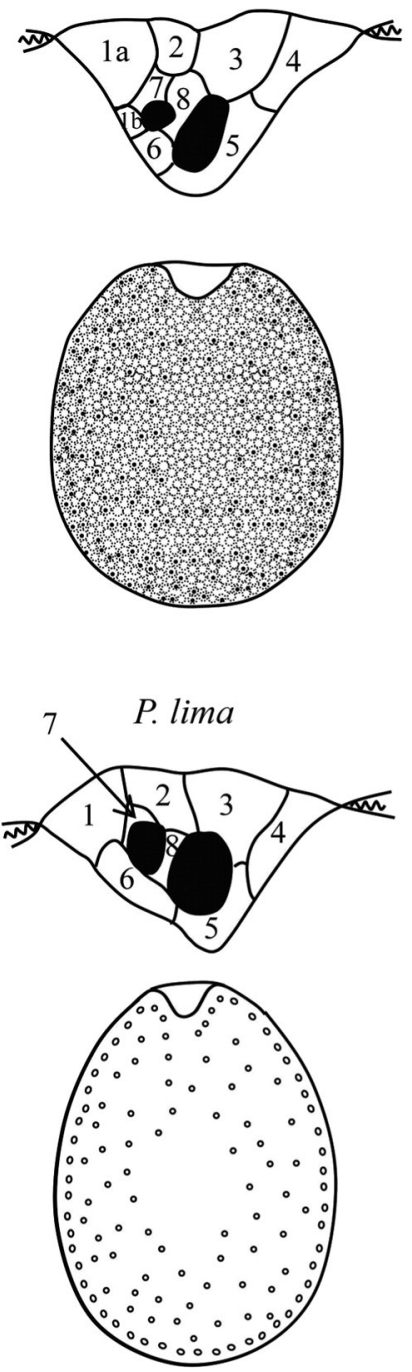

P. rhathymum
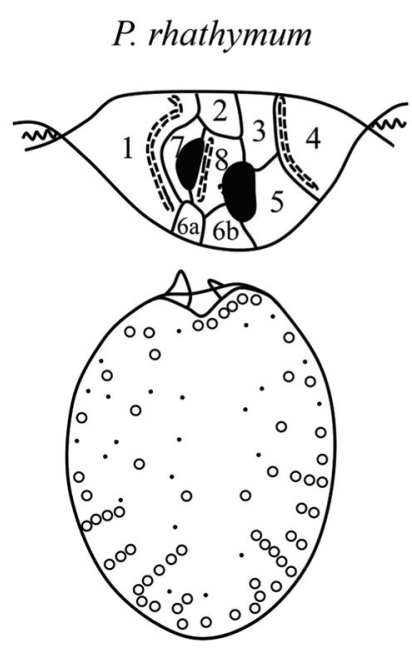

P. cf. emarginatum
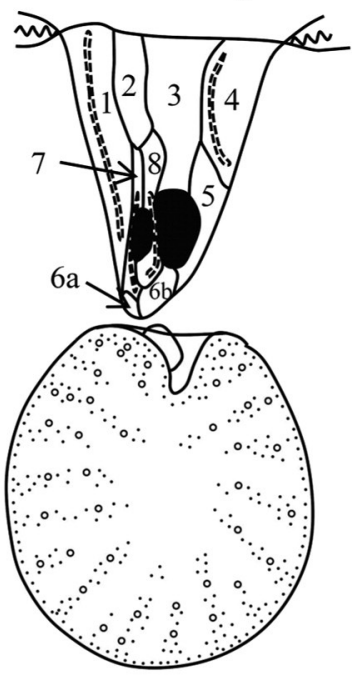

P. cf. maculosum
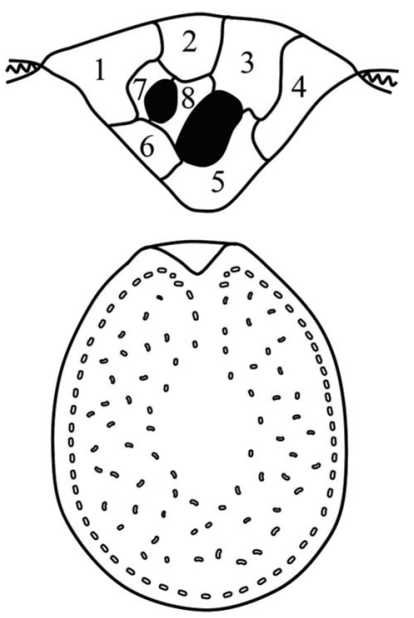

P. fukuyoi
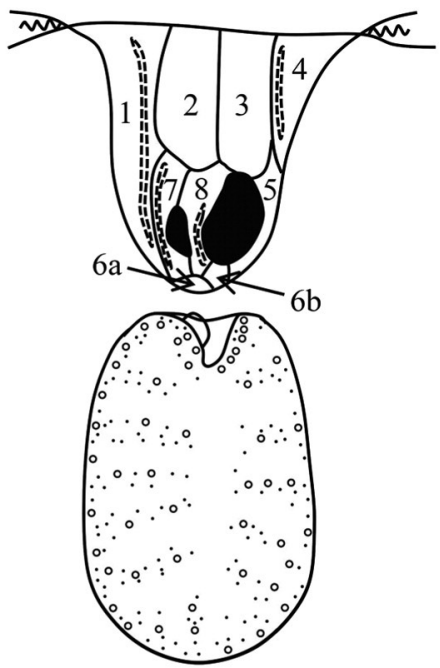

P. panamense
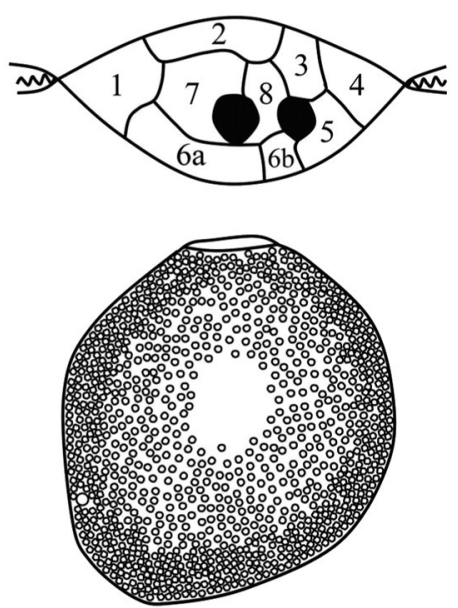

Fig. 9. Drawings of seven Prorocentrum species in right thecal view showing cell shape, periflagellar area, the pore pattern, and patterns of periflagellar platelets.

that $P$. concavum from the South China Sea does not produce detectable $\mathrm{OA}$, but whether it produces other kinds of toxins remains to be determined.
Only a few Chinese P. lima strains produced both OA and DTX-1, whereas all strains from the UK and Portugal produced these two toxins in varying quantities $[55,69]$. In previous studies, production of OA was 


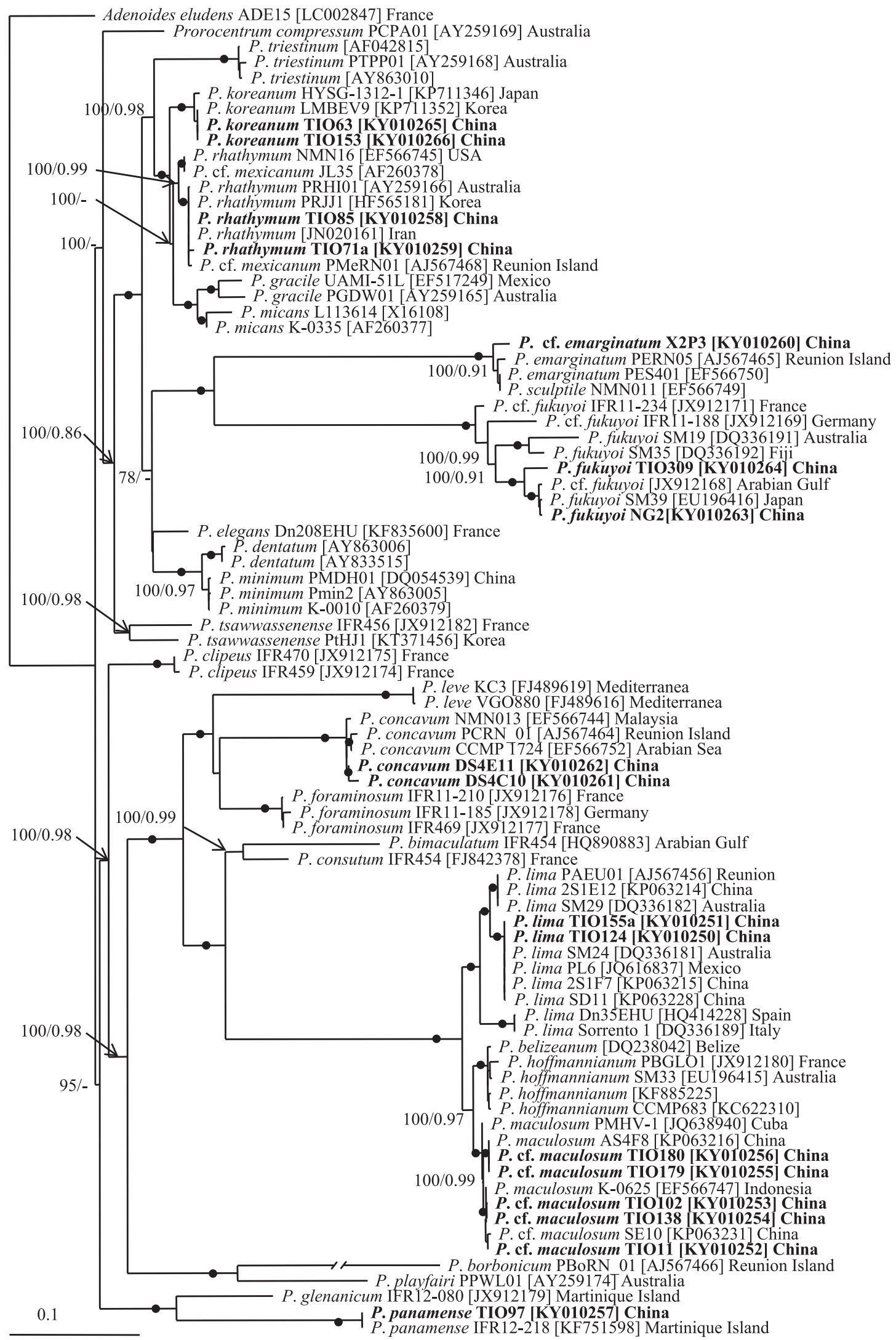

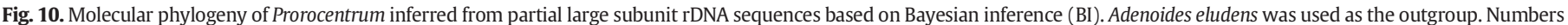

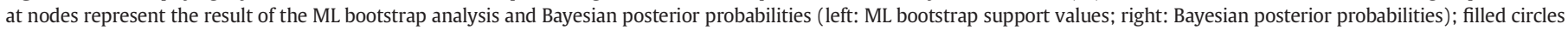

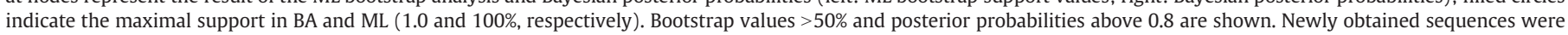
indicated as bold. Scale bar $=$ number of nucleotide substitutions per site. 


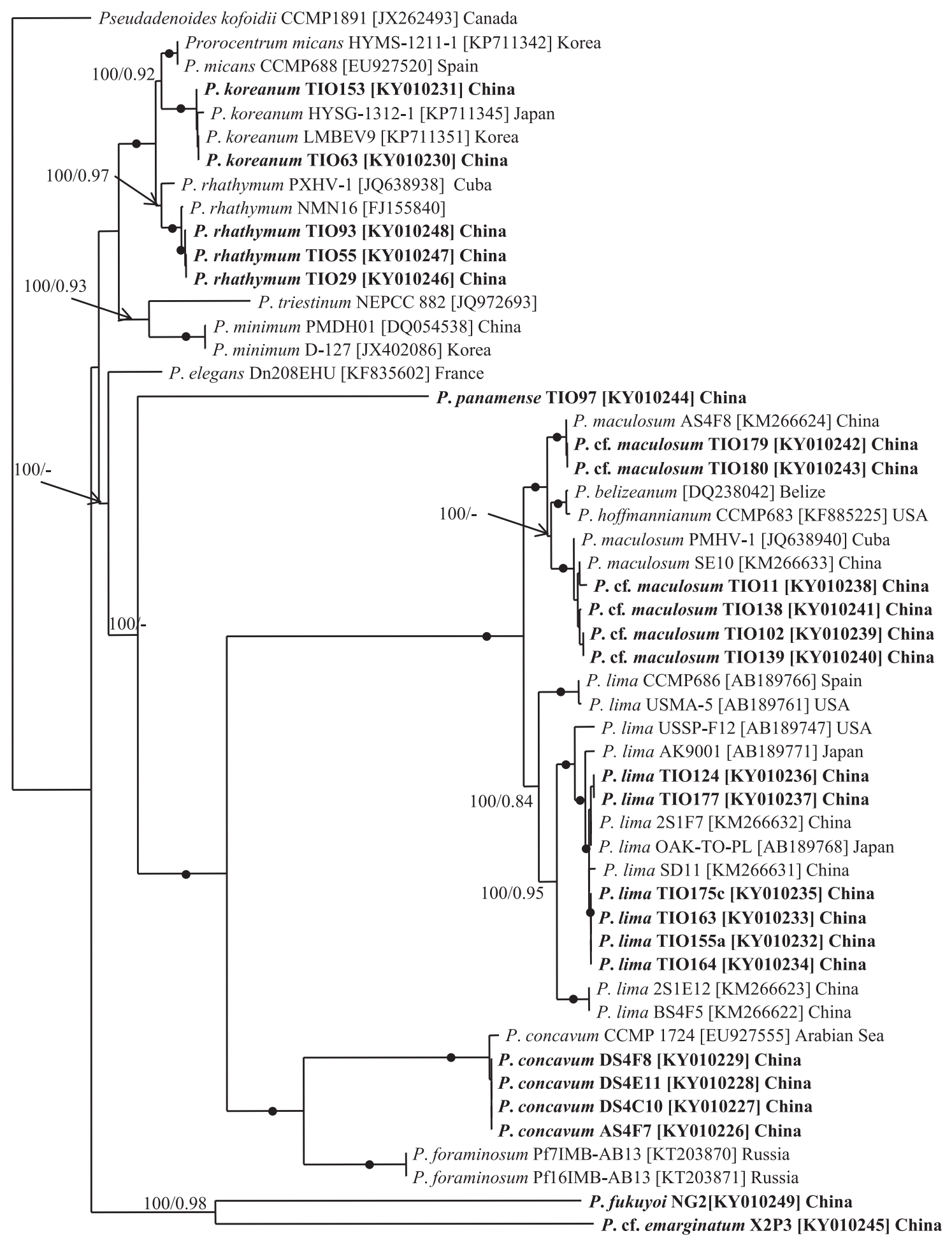

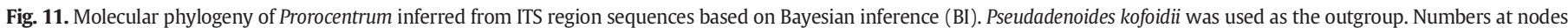

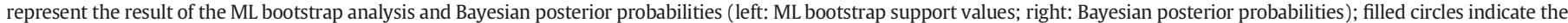

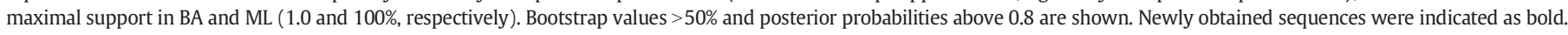
Scale bar $=$ number of nucleotide substitutions per site.

reported in only one Japanese strain and one Chinese strain $[37,40]$. OA concentrations of the Chinese strains ranged from 500 to $10,000 \mathrm{fg}$ cell $^{-1}$, supporting the idea that OA concentrations of geographically isolated strains are similar [55]. OA production has been reported in $P$. maculosum (originally as P. concavum) [34], but the species was probably P. hoffmannianum [33]. Zhou and Fritz [76] reported that $P$. maculosum was able to produce OA based on the results of the monoclonal antibody method. They stated that the culture was the same as that reported by Dickey et al. [14], but the cell morphology in the two studies was quite different in that the former had many depressions and the latter had fewer depression [75]. A possible explanation is that the depressions are plastic in $P$. hoffmannianum [33], thus P. maculosum might be a 
junior synonym of $P$. hoffmannianum. Our results support the premise that $P$. rhathymum does not always produce detectable $\mathrm{OA}[3,72]$ and that $P$. panamense is a nontoxic species. OA production has been reported in Dinophysis and related species [60], but they are phylogenetically distant from Prorocentrum [53], suggesting that OA production has evolved independently.

\section{Conclusion}

Seven epibenthic Prorocentrum species were identified from the northern South China Sea. Among them, P. panamense and P. maculosum have not been reported previously outside Central America. In addition to the shape of valve pores, $P$. cf. maculosum can be separated from $P$. lima by its inability to aggregate in culture. $P$. cf. emarginatum might be differentiated from $P$. fukuyoi based on the presence of marginal pores. OA was detected in all Chinese P. lima and $P$. cf. maculosum strains but not in the other three species.

Supplementary data to this article can be found online at http://dx. doi.org/10.1016/j.algal.2016.11.020.

\section{Acknowledgments}

We thank three anonymous reviewers for constructive suggestions that improved the ms. This project was supported by National Natural Science Foundation of China (31372535, 41376170, 41576162 and 41606176) and Research Fund for the Doctoral Program of Higher Education (20134401110009).

\section{References}

[1] T.H. Abe, The armored dinoflagellata. II. Prorocentridae and Dinophysidae, Publ Seto. Mar. Biol. Lab. 14 (1967) 369-389.

[2] M. Adachi, Y. Sake, Y. Ishida, Analysis of Alexandrium (Dinophyceae) species using sequences of the $5.8 \mathrm{~S}$ ribosomal DNA and internal transcribed spacer regions, J. Phycol. 32 (3) (1996) 424-432.

[3] K. Aligizaki, G. Nikolaidis, P. Katikou, A.D. Baxevanis, T.J. Abatzopoulos, Potentially toxic epiphytic Prorocentrum (Dinophyceae) species in Greek coastal waters, Harmful Algae 8 (2) (2009) 299-311.

[4] A. Almazán-Becerril, S. Escobar-Morales, G. Rosiles-González, F. Valadez, Benthicepiphytic dinoflagellates from the northern portion of the Mesoamerican Reef System, Bot. Mar. 58 (2) (2015) 115-128.

[5] T. An, J. Winshell, G. Scorzetti, J.W. Fell, K.S. Rein, Identification of okadaic acid production in the marine dinoflagellate Prorocentrum rhathymum from Florida Bay, Toxicon 55 (2) (2010) 653-657.

[6] A. Boc, A.B. Diallo, V. Makarenkov, T-REX: a web server for inferring, validating and visualizing phylogenetic trees and networks, Nucleic Acids Res. 40 (2012) W573-W579.

[7] N. Bouaıcha, A. Chézeau, J. Turquet, J.P. Quod, S. Puiseux-Dao, Morphological and toxicological variability of Prorocentrum lima clones isolated from four locations in the south-west Indian Ocean, Toxicon 39 (8) (2001) 1195-1202.

[8] A. Caillaud, P. de la Iglesia, M. Campàs, L. Elandaloussi, M. Fernández, N. Mohammad-Noor, K. Andree, J. Diogène, Evidence of okadaic acid production in a cultured strain of the marine dinoflagellate Prorocentrum rhathymum from Malaysia, Toxicon 55 (2) (2010) 633-637.

[9] H. Carroll, W. Beckstead, T. O'Connor, M. Ebbert, M. Clement, Q. Snell, D. McClellan, DNA reference alignment benchmarks based on tertiary structure of encoded proteins, Bioinformatics 23 (19) (2007) 2648-2649.

[10] L. Cienkowski, Bericht über eine Exkursion ins weisse Meer um Jahre 1880, Trav Soc. Imp. Nat. St. Petersb. 12 (1) (1881) 130-171.

[11] N. Chomérat, F. Zentz, S. Boulben, G. Bilien, A. van Wormhoudt, E. Nézan, Prorocentrum glenanicum sp. nov. and Prorocentrum pseudopanamense sp. nov. (Prorocentrales, Dinophyceae), two new benthic dinoflagellate species from South Brittany (northwestern France), Phycologia 50 (2) (2011) 202-214.

[12] R. Cortes-Altamirano, A.P. Sierra-Beltrán, Morphology and taxonomy of Prorocentrum mexicanum and reinstatement of Prorocentrum rhathymum (Dinophyceae), J. Phycol. 39 (1) (2003) 221-225.

[13] N. Daugbjerg, G. Hansen, J. Larsen, Ø. Moestrup, Phylogeny of some of the majo genera of dinoflagellates based on ultrastructure and partial LSU rDNA sequence data, including the erection of three new genera of unarmoured dinoflagellates, Phycologia 39 (4) (2000) 302-317.

[14] R.W. Dickey, S.C. Bobzin, D.J. Faulkner, F.A. Bencsath, D. Andrzejewski, Identification of okadaic acid from a Caribbean dinoflagellate, Prorocentrum concavum, Toxicon 28 (4) (1990) 371-377.

[15] D. Diego, L.T. Guillermo, D. Ramón, P. David, jModelTest 2: more models, new heuristics and parallel computing, Nat. Methods 9 (8) (2012) 772.
[16] J.D. Dodge, The Prorocentrales (Dinophyceae). II. Revision of the taxonomy within the genus Prorocentrum, Bot. J. Linnean Soc. 71 (1975) 103-125.

[17] C.G. Ehrenberg, Dritter Beitrag zur Erkenntnis grosser Organisationen in der Richtung des kleinsten Raumes, Abh. Akad. Wiss. Berlin (Phys. Kl.) 1833 (1833) 145-336.

[18] M. Faust, Morphologic details of six benthic species of Prorocentrum (Pyrrophyta) from a mangrove island, Twin Cays, Belize, including two new species, J. Phycol. 26 (3) (1990) 548-558.

[19] M. Faust, Morphology of ciguatera-causing Prorocentrum lima (Pyrrophyta) from widely differing sites, J. Phycol. 27 (5) (1991) 642-648.

[20] M. Faust, Three new benthic species of Prorocentrum (Dinophyceae) from Twin Cays, Belize: P. maculosum sp. nov., P. foraminosum sp. nov. and P. formosum sp. nov. Phycologia 32 (6) (1993) 410-418.

[21] M.A. Faust, Three new benthic species of Prorocentrum (Dinophyceae) from Carrie Bow Cay, Belize: P. sabulosum sp. nov., $P$. sculptile sp. nov., and $P$. arenarium $\mathrm{sp.}$ nov. J. Phycol. 30 (1) (1994) 755-763.

[22] M.A. Faust, M.W. Vandersea, S. Kibler, P.A. Tester, R.W. Litaker, Prorocentrum levis, a new benthic species (Dinophyceae) from a mangrove island, Twin Cays, Belize, J. Phycol. 44 (1) (2008) 232-240.

[23] R.A. Fensome, F.J.R. Taylor, G. Norris, W.A.S. Sarjeant, D.I. Wharton, G.L. Williams, A classification of fossil and living dinoflagellates, 7, Micropaleontology Special Publication, 1993 1-245.

[24] Y. Fukuyo, Taxonomical study on benthic dinoflagellates collected in coral reefs, Bull. Jpn. Soc. Sci. Fish. 47 (8) (1981) 967-978.

[25] D. Grzebyk, Y. Sako, B. Berland, Phylogenetic analysis of nine species of Prorocentrum (Dinophyceae) inferred from $18 \mathrm{~S}$ ribosomal DNA sequences, morphological comparisons, and description of Prorocentrum panamensis, sp. nov. J. Phycol. 34 (6) (1998) 1055-1068.

[26] R.R.L. Guillard, P.E. Hargraves, Stichochrysis immobilis is a diatom, not a chrysophyte, Phycologia 32 (3) (1993) 234-236.

[27] R.R.L. Guillard, J.H. Ryther, Studies of marine planktonic diatoms. I. Cyclotella nana Hustedt, and Detonula confervacea (Cleve) Gran, Can. J. Microbiol. 8 (2) (1962) 229-239.

[28] T.A. Hall, BioEdit: a user-friendly biological sequence alignment editor and analysis program for Windows 95/98/NT, Nucleic Acids Symp. Ser. 41 (1999) 95-98.

[29] D.W. Henrichs, P.S. Scott, K.A. Steidinger, R.M. Errera, A. Abraham, L Campbell, Morphology and phylogeny of Prorocentrum texanum sp. nov. (Dinophyceae): a new toxic dinoflagellate from the Gulf of Mexico coastal waters exhibiting two distinct morphologies, J. Phycol. 49 (1) (2013) 143-155.

[30] A. Herrera-Sepúlveda, L.K. Medlin, G. Murugan, A.P. Sierra-Beltrán, A.A. CruzVillacorta, N.Y. Hernández-Saavedra, Are Prorocentrum hoffmannianum and Prorocentrum belizeanum (Dinophyceae, Prorocentrales), the same species? An integration of morphological and molecular data, J. Phycol. 51 (1) (2015) 173-188

[31] C.F. Holmes, H.A. Luu, F. Carrier, F.J. Schmitz, Inhibition of protein phosphatases-1 and -2A with acanthifolicin, FEBS Lett. 270 (1-2) (1990) 216-218.

[32] M.J. Holmes, F.C. Lee, H.W. Khoo, S.L.M. Teo, Production of 7-deoxy-okadaic acid by a new caledonian strain of Prorocentrum lima (Dinophyceae), J. Phycol. 37 (2) (2001) 280-288.

[33] M. Hoppenrath, N. Chomérat, T. Horiguchi, M. Schweikert, Y. Nagahama, S. Murray, Taxonomy and phylogeny of the benthic Prorocentrum species (Dinophyceae) -a proposal and review, Harmful Algae 27 (2013) 1-28.

[34] T. Hu, J.M. Curtis, J.A. Walter, J.L. McLachlan, J.L. Wright, Two new water-soluble DSP toxin derivatives from the dinoflagellate Prorocentrum maculosum: possible storage and excretion products, Tetrahedron Lett. 36 (51) (1995) 9273-9276.

[35] T. Hu, J. Marr, A.S. de Freitas, M.A. Quilliam, J.A. Walter, J.L. Wright, S. Pleasance, New diol esters isolated from cultures of the dinoflagellates Prorocentrum lima and Prorocentrum concavum, J. Nat. Prod. 55 (11) (1992) 1631-1637.

[36] K. Katoh, D.M. Standley, MAFFT multiple sequence alignment software version 7: improvements in performance and usability, Mol. Biol. Evol. 30 (4) (2013) 772-780.

[37] K. Koike, S. Sato, M. Yamaji, Y. Nagahama, Y. Kotaki, T. Ogata, M. Kodama, Occurrence of okadaic acid-producing Prorocentrum lima on the Sanriku coast, northern Japan, Toxicon 36 (12) (1998) 2039-2042.

[38] B. Krock, U. Tillmann, U. John, A. Cembella, LC-MS-MS aboard ship: tandem mass spectrometry in the search for phycotoxins and novel toxigenic plankton from the North Sea, Anal. Bioanal. Chem. 392 (5) (2008) 797-803.

[39] J. Larsen, N. Nguyen, Potentially toxic microalgae of Vietnamese waters, Opera Bot. 140 (2004) 5-216

[40] C.P. Leaw, P.T. Lim, A. Ahmad, G. Usup, Genetic diversity of Ostreopsis ovata (Dinophyceae) from Malaysia, Mar. Biotechnol. 3 (3) (2001) 246-255.

[41] J. Li, M. Li, J. Pan, J. Liang, Y. Zhou, J. Wu, Identification of the okadaic acid-based toxin profile of a marine dinoflagellate strain Prorocentrum lima by LC-MS/MS and NMR spectroscopic data, J. Sep. Sci. 35 (7) (2012) 782-789.

[42] J. Liang, W. He, C. Long, L. Zeng, L. Long, Prorocentrum rhathymum-the first epiphyletic dinoflagellate record in the South China Sea, J. Trop. Bot. 19 (1) (2011) 40-44 (in Chinese with English abstract)

[43] A.R. Loeblich, J.L. Sherley, R.J. Schmidt, The correct position of flagellar insertion in Prorocentrum and description of Prorocentrum rhathymum sp. nov. (Pyrrhophyta), J. Plankton Res. 1 (2) (1979) 113-120.

[44] C.K. Lu, Y.M. Chen, S.H. Wang, Y.Y. Wu, Y.M. Cheng, Formosalides A and B, cytotoxic 17-membered ring macrolides from a marine dinoflagellate Prorocentrum sp. Tetrahedron Lett. 50 (16) (2009) 1825-1827.

[45] C.K. Lu, H.N. Chou, C.K. Lee, T.H. Lee, Prorocentin, a new polyketide from the marine dinoflagellate Prorocentrum lima, Org. Lett. 7 (18) (2005) 3893-3896.

[46] Ø. Moestrup, N. Daugbjerg, On dinoflagellate phylogeny and classification, in: J. Brodie, et al., (Eds.), 2007, Unravelling the Algae: The Past, Present, and Future of 
Algal Systematics. The Systematics Association Special Volume Series, Vol. 75, 2007, pp. 215-230.

[47] N. Mohammad-Noor, N. Daugbjerg, Ø. Moestrup, A. Anton, Marine epibenthic dinoflagellates from Malaysia-a study of live cultures and preserved samples based on light and scanning electron microscopy, Nord. J. Bot. 24 (6) (2005) 629-690.

[48] N. Mohammad-Noor, Ø. Moestrup, N. Daugbjerg, Light, electron microscopy and DNA sequences of the dinoflagellate Prorocentrum concavum (syn. P. arabianum) with special emphasis on the periflagellar area, Phycologia 46 (5) (2007) 549-564

[49] S.L. Morton, J.W. Bomber, Maximizing okadaic acid content from Prorocentrum hoffmannianum Faust, J. Appl. Phycol. 6 (1) (1994) 41-44.

[50] S.L. Morton, M.A. Faust, E.A. Fairey, P.D. Moeller, Morphology and toxicology of Prorocentrum arabianum sp. nov., (Dinophyceae) a toxic planktonic dinoflagellate from the Gulf of Oman, Arabian Sea, Harmful Algae 1 (4) (2002) 393-400.

[51] S.L. Morton, P.D. Moeller, K. Young, B. Lanoue, Okadaic acid production from the marine dinoflagellate Prorocentrum belizeanum Faust isolated from the Belizean coral reef ecosystem, Toxicon 36 (1) (1998) 201-206.

[52] Y. Murakami, Y. Oshima, T. Yasumoto, Identification of okadaic acid as a toxic component of a marine dinoflagellate Prorocentrum lima, Bull. Jpn. Soc. Sci. Fish. 48 (1) (1982) 69-72.

[53] S. Murray, C.L. Ip, R. Moore, Y. Nagahama, Y. Fukuyo, Are prorocentroid dinoflagellates monophyletic? A study of 25 species based on nuclear and mitochondrial genes, Protist 160 (1) (2009) 245-264.

[54] S. Murray, Y. Nagahama, Y. Fukuyo, Phylogenetic study of benthic, spine-bearing prorocentroids, including Prorocentrum fukuyoi sp. nov. Phycol. Res. 55 (1) (2007) 91-102.

[55] S.M. Nascimento, D.A. Purdie, S. Morris, Morphology, toxin composition and pigment content of Prorocentrum lima strains isolated from a coastal lagoon in southern UK, Toxicon 45 (5) (2005) 633-649.

[56] Y. Nagahama, Y. Fukuyo, Redescription of Cryptomonas lima, collected from Sorrento, Italy, the basionym of Prorocentrum lima, Plankton Biol. Ecol. 52 (2) (2005) 100-106.

[57] Y. Nagahama, S. Murray, A. Tomaru, Y. Fukuyo, Species boundaries in the toxic dinoflagellate Prorocentrum lima (Dinophyceae, Prorocentrales), based on morphological and phylogenetic characters, J. Phycol. 47 (2011) 178-189.

[58] J.A.A. Nylander, J.C. Wilgenbusch, D.L. Warren, D.L. Swofford, AWTY (are we there yet?): a system for graphical exploration of MCMC convergence in Bayesian phylogenetics, Bioinformatics 24 (4) (2008) 581-583.

[59] R.J.S. Orr, S.A. Murray, A. Stüken, L. Rhodes, K.S. Jakobsen, When naked became armored: an eight-gene phylogeny reveals monophyletic origin of theca in dinoflagellates, PLoS One 7 (11) (2012), e50004.

[60] N. Raho, G. Pizarro, L. Escalera, B. Reguera, I. Marín, Morphology, toxin composition and molecular analysis of Dinophysis ovum Schütt, a dinoflagellate of the "Dinophysis acuminata complex", Harmful Algae 7 (6) (2008) 839-848.

[61] F. Ronquist, M. Teslenko, P. van der Mark, D.L. Ayres, A. Darling, S. Höhna, B. Larget, L. Liu, M.A. Suchard, J.P. Huelsenbeck, MrBayes 3.2: efficient bayesian phylogenetic inference and model choice across a large model space, Syst. Biol. 61 (3) (2012) 539-542.

[62] M. Saburova, F. Al-Yamani, I. Polikarpov, Biodiversity of free-living flagellates in Kuwait's intertidal sediments, BioRisk 3 (2009) 97-110.

[63] C.A. Scholin, M. Herzog, M. Sogin, D.M. Anderson, Identification of group-and strainspecific genetic markers for globally distributed Alexandrium (Dinophyceae). II. Sequence analysis of a fragment of the LSU rRNA gene. J. Phycol. 30 (6) (1994) 999-1011.

[64] A. Stamatakis, RAxML-VI-HPC: maximum likelihood-based phylogenetic analyses with thousands of taxa and mixed models, Bioinformatics 22 (21) (2006) 2688-2690.

[65] K. Tachibana, P.J. Scheuer, Y. Tsukitani, H. Kikuchi, D. Van Engen, J. Clardy, Y. Gopichand, F.J. Schmitz, Okadaic acid, a cytotoxic polyether from two marine sponges of the genus Halichondria, J. Am. Chem. Soc. 103 (9) (1981) 2469-2471.

[66] A. Takai, C. Bialojan, M. Troschka, J. Caspar Rüegg, Smooth muscle myosin phosphatase inhibition and force enhancement by black sponge toxin, FEBS Lett. 217 (1) (1987) 81-84.

[67] L.c. Ten-Hage, N. Delaunay, V. Pichon, A. Couté, S. Puiseux-Dao, J. Turquet, Okadaic acid production from the marine benthic dinoflagellate Prorocentrum arenarium Faust (Dinophyceae) isolated from Europa Island coral reef ecosystem (SW Indian Ocean), Toxicon 38 (8) (2000) 1043-1054.

[68] P. Vale, M.A.d.M. Sampayo, First confirmation of human diarrhoeic poisonings by okadaic acid esters after ingestion of razor clams (Solen marginatus) and green crabs (Carcinus maenas) in Aveiro lagoon, Portugal and detection of okadaic acid esters in phytoplankton, Toxicon 40 (7) (2002) 989-996.

[69] P. Vale, V. Veloso, A. Amorim, Toxin composition of a Prorocentrum lima strain isolated from the Portuguese coast, Toxicon 54 (2) (2009) 145-152.

[70] V.Velikova, J. Larsen, The Prorocentrum cordatum/Prorocentrum minimum taxonomic problem, Grana 38 (2-3) (1999) 108-112.

[71] H. Wu, J. Yao, M. Guo, Z. Tan, D. Zhou, Y. Zhai, Distribution of marine lipophilic toxins in shellifish products collected from the Chinese market, Mar. Drugs 13 (7) (2015) 4281-4295.

[72] T. Yasumoto, N. Seino, Y. Murakami, M. Murata, Toxins produced by benthic dinoflagellates, Biol. Bull. 172 (1) (1987) 128-131.

[73] H. Zhang, D. Bhattacharya, S. Lin, A three-gene dinoflagellate phylogeny suggests monophyly of Prorocentrales and a basal position for Amphidinium and Heterocapsa, J. Mol. Evol. 65 (5) (2007) 463-474.

[74] H. Zhang, Y. Li, J. Cen, H. Wang, L. Cui, Y. Dong, S. Lu, Morphotypes of Prorocentrum lima (Dinophyceae) from Hainan Island, South China Sea: morphological and molecular characterization, Phycologia 54 (5) (2015) 503-516.

[75] J. Zhou, L. Fritz, Ultrastructure of two toxic marine dinoflagellates, Prorocentrum lima and Prorocentrum maculosum, Phycologia 32 (6) (1993) 444-450.

[76] J. Zhou, L. Fritz, Okadaic acid antibody localizes to chloroplasts in the DSP-toxin-producing dinoflagellates Prorocentrum lima and Prorocentrum maculosum, Phycologia 33 (6) (1994) 455-461. 